Original Research

\title{
PKG II secreted via the classical endoplasmic reticulum-Golgi apparatus secretory pathway blocks the activation of EGFR through phosporalting its threonine 406 and has an anti-tumor effect
}

\author{
Yan $\mathrm{Wu}^{1, *, \dagger}$, Min $\mathrm{Wu}^{1, \dagger}$, Zibin Wang ${ }^{2}$, Ji Pang ${ }^{1}$, Miaolin $\mathrm{Zhu}^{1,3}$, Ting Lan ${ }^{1}$, Xiaoyuan Yao ${ }^{1}$, \\ Hai Qian ${ }^{1}$, Xinyue Lin $^{1}$, Lu Jiang ${ }^{1}$, Yan Tao ${ }^{1}$, Yujie Zhang ${ }^{4}$, Yongchang Chen ${ }^{1, *}$ \\ ${ }^{1}$ Department of Physiology, School of Medicine, Jiangsu University, 212013 Zhenjiang, Jiangsu, China \\ ${ }^{2}$ Analytical and Testing Center, Nanjing Medical University, 211166 Nanjing, Jiangsu, China \\ ${ }^{3}$ Department of Pathology, Jiangsu Cancer Hospital, 210009 Nanjing, Jiangsu, China \\ ${ }^{4}$ Department of Physiology, Nanjing Medical University, 211166 Nanjing, Jiangsu, China \\ *Correspondence: 1000007247@ujs.edu.cn (Yongchang Chen); wuyan81@ujs.edu.cn; jsdxwuyan@163.com (Yan Wu) \\ ${ }^{\dagger}$ These authors contributed equally. \\ Academic Editors: Zahid Pranjol and Georgios Giamas \\ Submitted: 18 December 2021 Revised: 17 January 2022 Accepted: 19 January 2022 Published: 11 February 2022
}

\begin{abstract}
Background: Protein kinase G type II (PKG II) is a serine/threonine-protein kinase that was originally isolated from the small intestinal mucosa with primary functions in the secretion of small intestinal mucosal cells, secretion of renin and aldosterone, and chondrocyte activities. Recent studies have shown that PKG II exerts anti-tumor effects, while a previous study by our group confirmed that PKG II inhibited the proliferation and migration of cancer cells. Interestingly, PKG II, which was typically bound to the intracellular side of the membrane, was detected in the serum and cell culture medium as a diagnostic biomarker of tumor growth. Thus, the aim of the present study was to elucidate the function and the targets of PKG II, and the mechanism underlying the secretion of this kinase. Methods: Construction of peptides and plasmids, RNA interference, Immunoelectron microscopy, Co-immunoprecipitation, N-glycosylation assay and Isolation of the Golgi apparatus were applied to investigate the secretory mechanism, and the targets and function of PKG II. Results: PKG II was secreted by enterochromaffin (EC) cells, which were components of the endocrine system in the gastrointestinal tract. Myristoylation of glycine 2 and the N-terminal sequence, especially the amino acids 3-30, acted as a signal peptide to induce the secretion of PKG II via the conventional protein secretory pathway. Moreover, recombinant PKG II inhibited the epidermal growth factor (EGF)induced activation of the EGF receptor via phosphorylating the T406 of the extracellular domain and blocked EGF-triggered proliferation of various cancer cells. Conclusions: These results revealed a correlation between the endocrine system and the secretion of protein kinase, suggesting a novel protein secretory pathway. The resuls also indicated that secreted PKG II was a potential diagnostic biomarker and an inhibitor of tumor.
\end{abstract}

Keywords: enterochromaffin cells; protein kinase G type II; protein secretion; epidermal growth factor receptor; threonine 406

\section{Introduction}

Protein Kinases are a heterogeneous family of enzymes modulating several biological pathways, including cell survival, differentiation and apoptosis [1]. As a serine/threonine-protein kinase, Protein kinase G type II (PKG II) was first detected as a membrane-bound receptor of cyclic guanosine monophosphate (cGMP) in the intestinal epithelium [2] and later found to bind to the cellular membrane via a myristoyl moiety attached to the Nterminus of the amino acid (aa) chain [3]. PKG II has been implicated in several physiological functions, including intestinal secretion, bone growth, and learning and memory [4], and more recently in regulation of the sodium channels of intestinal epithelial cells and mechanical signaling of osteoblasts [5-7]. In addition, PKG II plays a role in regulating cell proliferation and apoptosis [8,9], which might be potentially associated with tumorigenesis. Our group confirmed that PKG II could inhibit the proliferation and mi- gration of gastric cancer cells by blocking epidermal growth factor (EGF)-induced activation of the epidermal growth factor receptor (EGFR) [10,11]. Surprisingly, an investigation of the mechanism underlying the influence of PKG II on EGFR found that PKG II could be secreted into the extracellular fluid and PKG II serum levels of cancer patients were significantly downregulated, and the above results indicated that the PKG II could be used as a tumor diagnostic marker. However, since PKG II is an intracellular protein without a signal peptide, the effect and roles of secreted PKG II remain unclear. Therefore, the aim of the present study was to clarify the mechanism of secretion and the extracellular effects and targets of PKG II.

\section{Materials and methods}

\subsection{Materials}

The gastric cancer cell lines AGS and HGC-27, colon cancer cell line SW480, hepatic cancer cell line HepG2, 
breast cancer cell line MCF-7, human embryonic kidney cell line 293, and fibroblast-like cell line COS-7 derived from monkey kidney tissue were obtained from the Institute of Biochemistry and Cell Biology, Shanghai Institute for Biological Sciences, Chinese Academy of Sciences (Shanghai, China). The gastric mucosal epithelial cell line GES-1 and the gastric cancer cell lines SGC-7901 and BGC-823 were got from Jiangsu University (Jiangsu, China). F-12K medium (Kaighn's modification of Ham's F-12 medium), Dulbecco's modified Eagle's medium (DMEM), and fetal bovine serum (FBS) were purchased from Gibco (Thermo Fisher Scientific, Inc., Waltham, MA, USA). Plasmids encoding the complementary DNA (cDNA) of mutant EGFRs were constructed in our laboratory. Adenoviral vectors encoding the cDNA of PKG II (Ad-PKG II) were kind gifts from Dr. Gerry Boss and Dr. Renate Pilz of the University of California, San Diego (San Diego, CA, USA). Recombinant glutathione S-transferase (GST)-tagged PKG II (GST-PKG II) was obtained from SignalChem Lifesciences Corporation (Richmond, BC, Canada). Antibodies (Abs) against $\beta$-actin, G-6-Pase, NMT-1, p-Tyr (PY99), and His-tag were purchased from Santa Cruz Biotechnology, Inc. (Dallas, TX, USA). Abs against phospho (p) and total EGFR, ERK, c-Raf, MEK, PI3K, and Akt were obtained from Cell Signaling Technology (Danvers, MA, USA). Abs against p- Ser/Thr and Flag-tag protein were purchased from Abcam (Cambridge, MA, USA) and Sigma-Aldrich Corporation (St. Louis, MO, USA), respectively. Abs against GM130 and GRP78 were purchased from Bioworld Technology, Inc. (St. Louis Park, MN, USA). Abs against SRP54 was from Proteintech Group, Inc. (Rosemont, IL, USA). Abs against PKG II were purchased from Santa Cruz Biotechnology, Inc. (Dallas, TX, USA) or Abcam (Cambridge, MA, USA). Horseradish peroxidase-conjugated secondary Abs were obtained from Jackson ImmunoResearch Laboratories, Inc. (West Grove, PA, USA). All antibodies were used in accordance with the dilutions recommended by the instructions. Brefeldin A and Tris(dibenzylideneacetone)dipalladium (DBA) were purchased from MilliporeSigma (St. Louis, MO, USA). PNGase F was from New England Biolabs, Inc. (Ipswich, MA, USA), and electrochemiluminescence reagent was from EMD Millipore Corporation.

\subsection{Mice and human serum samples}

Female nude BALB/c mice (age, 6 weeks) were purchased from the Animal Center of Yangzhou University (Yangzhou, Jiangsu, China) and housed in the Animal Center of Jiangsu University in compliance with the Guide for the Care and Use of Laboratory Animals (NIH,76 FR 91; May 11, 2011). The protocols of the mouse experiments were approved by the Institutional Animal Care and Use Committee of Jiangsu University. Human serum samples were collected from healthy volunteers $(n=24)$, patients with gastric cancer $(n=42)$, and patients with colorectal cancer $(\mathrm{n}=20)$ at the Affiliated Hospital of Jiangsu University (Zhenjiang, China). The study protocol involving human subjects was approved by the Medical Ethics Committee of Jiangsu University and written informed consent was obtained from each subject prior to participation in this study.

\subsection{Methods}

2.3.1 Cell culture and preparation of cell membrane fractions

The cells were cultured in DMEM or F-12K medium supplied with $10 \%$ FBS under a humidified atmosphere of $5 \% \mathrm{CO}_{2} / 95 \%$ air at $37{ }^{\circ} \mathrm{C}$ with medium changes every 2 days until confluence. Thereafter, the cells were subcultured the day before transfection with plasmids or siRNA with the use of Lipofectamine 2000 reagent (Invitrogen Corporation, Carlsbad, CA, USA) in accordance with the manufacturer's protocol. Upon reaching confluence of 70$80 \%$, the cells were infected and cultured with Ad-PKG II at a multiplicity of infection of about $100 \%$ and harvested about 24-48 h later in accordance with the experimental protocol. Cell membranes and cytosol were isolated combined with the reference [12] and Membrane and Cytosol Protein Extraction Kit (Beyotime Institute of Biotechnology, Shanghai, China)

\subsubsection{Protein concentration from cell culture medium}

The culture medium was harvested into polypropylene tubes and centrifuged at $2000 \times \mathrm{g}$ for $5 \mathrm{~min}$. The supernatant (up to $500 \mu \mathrm{L}$ ) was transferred into an Amicon ${ }^{\circledR}$ Ultra-2 centrifugal filter device (EMD Millipore Corporation) and centrifuged at $14,000 \times \mathrm{g}$ for $30 \mathrm{~min}$. Afterward, the assembled Amicon ${ }^{\circledR}$ device was removed from the centrifuge and separated from the micro-centrifuge tube. To recover the concentrated solute, the Amicon ${ }^{\circledR}$ device was placed upside down in a clean microcentrifuge tube and spun at $1000 \times \mathrm{g}$ for $2 \mathrm{~min}$ to transfer the concentrated sample into the tube.

\subsubsection{Western blot (WB)}

Protein samples were separated based on molecular size by electrophoresis using $8-12 \%$ agarose gels and then transferred onto polyvinylidene fluoride membranes. The membranes were blocked with $5 \%(\mathrm{w} / \mathrm{v})$ non-fat milk in Tris-buffered saline with $0.1 \%$ Tween ${ }^{\circledR} 20$ detergent for $1 \mathrm{~h}$ at room temperature, then incubated with primary Abs at 4 ${ }^{\circ} \mathrm{C}$ for $12 \mathrm{~h}$, washed three time with Tris-buffered saline and incubated with secondary Abs at room temperature for $1 \mathrm{~h}$. The bands were visualized with electrochemiluminescence reagent.

\subsubsection{Cell proliferation assay}

Briefly, $2000-5000$ cells in $100 \mu \mathrm{L}$ of medium were seeded in the wells of a 96-well plate. Following serum starvation for $24 \mathrm{~h}$, recombinant PKG II with or without 
8-pCPT-cGMP $(250 \mu \mathrm{M})$ was added and the cells were incubated with or without EGF $(100 \mathrm{ng} / \mathrm{mL})$ for $24 \mathrm{~h}$. Cell proliferation was determined using the Cell Counting Kit- 8 (Sigma-Aldrich Corporation) in accordance with the manufacturer's instructions. Afterward, absorbance was measured at $450 \mathrm{~nm}$ using a microplate reader.

2.3.5 Subcutaneous transplantation of tumor cells in nude mice and treatment

Tumor growth was induced by subcutaneously injecting the flank of the nude mice with $2 \times 10^{6}$ BGC-823 cells. When the tumor increased in size to $6-9 \mathrm{~mm}^{3}$, the in vivo effect of recombinant PKG II on the growth of transplanted tumor cells was investigated. Briefly, active recombinant PKG II (400 ng/mouse) with or without 8pCPT-cGMP $(0.255 \mu \mathrm{g} /$ mouse $)$ was injected through multiple sites around the tumor every 3 days for 3 weeks. At the end of the experiment, the mice were sacrificed. The tumors were taken out, and the sizes and the weights of the tumors were calculated.

\subsubsection{Immunofluorescence and confocal microscopy}

The cells were plated on glass coverslips in the wells of a 24-well plate, treated, and then fixed with $4 \%$ paraformaldehyde for $12 \mathrm{~h}$ at $4{ }^{\circ} \mathrm{C}$. Afterward, the cells were washed with phosphate-buffered saline (PBS), incubated with $0.3 \%$ Triton $\mathrm{X}-100$ for $15 \mathrm{~min}, 5 \%$ bovine serum albumin (BSA) for $1 \mathrm{~h}$, the primary Abs for $3 \mathrm{~h}$, the corresponding secondary Abs for $1 \mathrm{~h}$, stained with Hoechst 33342 (in PBS) and then visualized with a confocal microscope (LEXT OLS4100; Olympus Corporation, Tokyo, Japan).

\subsubsection{Immunoelectron microscopy}

Tissues were fixed in $4 \%$ paraformaldehyde and $0.05 \%$ glutaraldehyde solution in $0.1 \mathrm{M}$ sodium phosphate buffer ( $\mathrm{pH} 7.0$ ) for $2 \mathrm{~h}$, rinsed with $0.1 \mathrm{M}$ phosphate buffer ( $\mathrm{pH}$ 7.0), dehydrated via a graded ethanol series, and embedded in LR White (London Resin Company Limited, Stansted, Essex, England, UK). After ultraviolet radiation for $72 \mathrm{~h}$ at $-25{ }^{\circ} \mathrm{C}$, Ultrathin sections were labeled with Abs against PKG II (Abcam) or chromogranin A (Abcam) at $4{ }^{\circ} \mathrm{C}$ overnight, followed by $10-\mathrm{nm}$ gold-conjugated immunoglobulin $\mathrm{G}$ secondary Abs at room temperature for 4 h. Micrographs were acquired using a transmission electron microscope (Tecnai G2 Spirit BioTWIN; FEI Company, Hillsboro, OR, USA).

\subsubsection{Co-immunoprecipitation (Co-IP)}

Cells grown on a $10-\mathrm{cm}$ culture dish were washed two times with cold PBS and lysed with cold immunoprecipitation assay buffer (Thermo Fisher Scientific, Inc.). The supernatant was obtained by centrifugation of the lysate at $12,000 \times \mathrm{g}$ for $30 \mathrm{~min}$, and then incubated with Abs against the target proteins for $12 \mathrm{~h}$ at $4{ }^{\circ} \mathrm{C}$, agarose-conjugated pro- tein $\mathrm{A} / \mathrm{G}$ for $2-3 \mathrm{~h}$ at $4{ }^{\circ} \mathrm{C}$. The reaction mixtures were centrifuged at $2000 \times \mathrm{g}$ for $1 \mathrm{~min}$ at $4{ }^{\circ} \mathrm{C}$. Then, the supernatant was discarded and the pellet was washed three times with binding buffer, resuspended in $2 \times$ sodium dodecyl sulfate sample buffer, and heated at $100{ }^{\circ} \mathrm{C}$ for $5 \mathrm{~min}$ and then analyzed by WB.

\subsubsection{N-glycosylation assay}

The cells were treated and then scraped into $1 \mathrm{~mL}$ of cold PBS, centrifuged at $600 \times \mathrm{g}$ for $5 \mathrm{~min}$. The pellet was resuspended in $100 \mu \mathrm{L}$ of cold double-distilled water, shake on the ice for 30-50 times, centrifuged at $700 \times \mathrm{g}$ for 10 min. And then $25 \mu \mathrm{L}$ of the supernatant were collected, mixed with $2.5 \mu \mathrm{L}$ of $10 \times$ glycoprotein denaturing buffer, and heated at $100{ }^{\circ} \mathrm{C}$ for $10 \mathrm{~min}$ to denature the proteins. Each $40-\mu \mathrm{L}$ reaction mixture, consisting of $4 \mu \mathrm{L}$ of $10 \times$ G7 Reaction Buffer, $4 \mu \mathrm{L}$ of $10 \%$ NP40, $3 \mu \mathrm{L}$ of PNGaseF, and $29 \mu \mathrm{L}$ of double-distilled water, was incubated at $37^{\circ} \mathrm{C}$ for $1 \mathrm{~h}$. As a control, a $20-\mu \mathrm{L}$ reaction mixture containing recombinant GST-PKG II was used for the same procedure. Following the addition of $2 \times$ loading buffer, the reaction mixture was heated at $100{ }^{\circ} \mathrm{C}$ for 5 min prior to WB analysis.

\subsubsection{Isolation of the Golgi apparatus (GA)}

The GA was extracted from HGC-27 cells $\left(5 \times 10^{7}\right)$ infected with Ad-PKG II for $24 \mathrm{~h}$ using Lionel's method [13] and a Golgi Isolation Kit (Sigma-Aldrich Corporation) in accordance with the manufacturer's instructions. Briefly, the cells were washed twice with PBS, then homogenized in a small volume of homogenization medium $(0.25 \mathrm{M}$ sucrose, $\mathrm{pH}$ 7.4), and then transferred into a centrifuge tube and centrifuged at $3000 \times \mathrm{g}$ for $15 \mathrm{~min}$ at $2-8{ }^{\circ} \mathrm{C}$. Following transfer to a new tube, the sucrose concentration in the supernatant was adjusted to $1.25 \mathrm{M}$ by adding an appropriate volume of $2.3 \mathrm{M}$ sucrose solution. A discontinuous gradient was prepared in an ultracentrifuge tube. The tubes were centrifuged at $120,000 \times \mathrm{g}$ for $3 \mathrm{~h}$ at $2-8{ }^{\circ} \mathrm{C}$. The GA-enriched fraction was withdrawn from the $1.1 \mathrm{M} / 0.25$ M sucrose interphase.

\subsubsection{Detection of PKG II in mouse serum}

Serum samples were collected from healthy female $\mathrm{BALB} / \mathrm{c}$ mice intraperitoneally injected with $10 \mathrm{mg} / \mathrm{kg}$ of Brefeldin A for 3 days. In addition, serum samples were collected from healthy female BALB/c mice intraperitoneally injected with $40 \mathrm{mg} / \mathrm{kg}$ of DBA once every 3 days, 6 times in total. For both groups, blood samples were collected at $48 \mathrm{~h}$ after the last injection by puncturing the posterior venous plexus of the eyeball, stored at room temperature for $2 \mathrm{~h}$, and then at $4{ }^{\circ} \mathrm{C}$ overnight. The next day, the samples were centrifuged to obtain serum. The PKG II content in mouse serum was determined using an enzymelinked immunosorbent assay (ELISA) kit (Wuhan USCN Business Co., Ltd., Wuhan, China) in accordance with the manufacturer's instructions. 
Table 1. The primers for the deletion plasmids of PKG II.

\begin{tabular}{ll}
\hline PKG II deletants & Primer sequence \\
\hline Del(3-8) & F: 5'-AAGCTTCCTGAGCAACATGGGAAAGCATTC-3' \\
Del(3-14) & F: 5'-AAGCTTCCTGAGCAACATGGGAGACGGCCA-3' \\
Del(3-20) & F:5'-AAGCTTGAGCAACATGGGACTCAGCAATGAA GCCCTG-3' \\
Del(3-26) & F:5'-AAGCTTGAGCAACATGGGACGGAGCAAAGTGGCAGAG-3' \\
Del(3-30) & F:5'-AAGCTTGAGCAACATGGGAGCAGAGCTGGAGCGCGAG-3' \\
Del(3-34) & F:5'-AAGCTTGAGCAACATGGGACGCGAGGTGAAGAGGAAG-3' \\
& R: 5'-TCTAGACTCTCCTGTCAGAAGTCCTTATCC-3' \\
Del(21-32) & F: 5'-AAGCTTATATCGAATTCCGTTGCTGTC-3' \\
& R: 5'-GTTCCCTGACTGGCCGTC-3'(short) \\
& F: 5'-CTGGAGCGCGAGGTGAAG-3' \\
& R: 5'-TCTAGACTCTCCTGTCAGAAGTCCTTATCC-3'(long)
\end{tabular}

\subsubsection{Construction of Ad-PKG II-G2A}

Site mutation Gly $2 \rightarrow$ Ala (G2A) was performed using the QuikChange site-directed mutagenesis kit (Agilent Technologies, Inc., Santa Clara, CA, USA) with the primers 5'-GTTCCTGAGCAACATGGCAAATGGTTCAGTGAAAC-3' and 5'GTTTCACTGAACCATTTGCCATGTTGCTCAGGAAC3'. The cDNA of PKG II-G2A was cloned and digested with the restriction endonucleases HindIII and XbaI. The purified plasmid DNA of the PKG II-G2A and pENTR1A vectors were digested with the restriction endonucleases XmnI and EcoRV, and then ligated using T4 ligase at $16{ }^{\circ} \mathrm{C}$ overnight. The cDNA of PKG II-G2A was directedly cloned into the pAd-CMV/V5-DEST plasmid from the pENTR1A-PKG II-G2A plasmid with Gateway $^{\mathrm{TM}}$ LR Clonase ${ }^{\mathrm{TM}}$ II Enzyme mix (Thermo Fisher Scientific, Inc.) to construct the recombinant plasmid pAd-CMV/V5-DEST-PKG II-G2A (Ad-PKG II-G2A).

\subsubsection{Construction of different PKG II deletants (PKG II-Del)}

For the deletion plasmids PKG II-Del(3-8), Del(314), Del(3-20), Del(3-26), Del(3-30), and Del(3-34), the HindIII and XbaI sequences were included to the 5 '-ends of the upstream and downstream primers. For the PKG II-Del(21-32) deletion plasmid, the HindIII and XbaI sequences were added to the $5^{\prime}$-end of the upstream primer for the shorter segment and the $5^{\prime}$-end of the downstream primer for the longer segment. The following primers were used for the deletion plasmids in Table 1. The PCR amplifications were performed according to the protocol of the Site-Directed Mutagenesis kit. The correct plasmids and pcDNA3.1-c-flag plasmid were digested with the restriction endonucleases HindIII and XbaI, then the products were collected for T4 ligation, and identified by digestion with HindIII and XbaI and sequenced.

\subsubsection{RNA interference}

Short-interfering RNAs (siRNAs) against SRP54 and a negative control were synthesized by RiboBio Co., Ltd. (Guangzhou, China). The nucleotide sequences of three siRNAs against SRP54 were GAAATGAACAGGAGTCAAT, GCAAGAGGATCGGGTGTAT, and GATCCTGTCATCATTGCTT reapectively. Transfection with siRNA was performed using Lipofectamine ${ }^{\mathrm{TM}} 2000$ reagent. After 4-6 h, the siRNA/lipid complexes were removed and the cells were maintained in complete medium for $48-72 \mathrm{~h}$. Afterward, the cells were harvested and the cell lysates were collected for WB analysis to detect the siRNA-induced inhibition of SRP54 protein expression.

\subsubsection{Peptide synthesis}

The peptides of PKG II-Myr-(2-30)-Flag (MyrGNGSVKPKHSKHPDGHSGNLTTDALRNKVDYKDDDDK) and PKG II-(2-30)-Flag (GNGSVKPKHSKHPDGHSGNLTTDALRNKVDYKDDDDK) were synthesized by ChinaPeptides Co., Ltd. (Hangzhou, China).

2.3.16 Construction of PKG II-(1-30)-green fluorescent protein (GFP) and PKG II-(1-30)-Ras homolog family member A (RhoA)-Flag peptides

The first 30 aa of PKG II were ligated into the plasmid pcDNA3.1-C-eGFP (6143 bp) to construct the peptide PKG II-(1-30)-GFP with the cloning sites HindIII and BamHI. The RhoA sequence was ligated to the plasmid pcDNA3.1+C-DYK (5438 bp) to construct the RhoA-Flag plasmid. The first 30 aa of PKG II were ligated to the Nterminus of RhoA-Flag to construct the peptide PKG II(1-30)-RhoA-Flag. The above plasmids were constructed by Nanjing Genscript Biotechnology Co., Ltd. (Nanjing, China).

\subsubsection{EGF-EGFR binding assay}

The cells were serum-starved for $12 \mathrm{~h}$, incubated with Alexa Flour 488-EGF, then fixed with 2\% paraformaldehyde and washed with PBS prior to Confocal Microscopy 
and Flow Cytometry. For the detailed steps, please refer to Thomas' paper [14].

\subsubsection{Transient transfection and immunoprecipitation.}

The cells were seeded into the wells of a six-well plate at a density of $1 \times 10^{6}$ cells/well. After $24 \mathrm{~h}$, transient transfection was performed using Lipofectamine ${ }^{\mathrm{TM}} 2000$ reagent. After an additional $24 \mathrm{~h}$, the cells were lysed by adding $1 \mathrm{~mL}$ of radioimmunoprecipitation assay buffer per well. Abs against Flag were used to precipitate Flag-tagged mutant EGFR.

\subsubsection{In vitro assay of the inhibitory effect of recombinant PKG II on isolated EGFR}

About $200 \mu \mathrm{g}$ of membrane proteins were suspended in $100 \mu \mathrm{L}$ of in vitro reaction mixture and $1 \mu \mathrm{L}$ of $100 \times$ protease inhibitor (Beyotime Institute of Biotechnology). To determine the inhibitory effect of recombinant PKG II on membrane-bound EGFR, the mixture was incubated with recombinant PKG II (150 $\mathrm{nM}, 20 \mathrm{~min})$ and then with 8pCPT-cGMP (400 $\mu \mathrm{M}, 20 \mathrm{~min}$ ) to active PKG II, and finally with EGF ( $4 \mu \mathrm{g} / \mathrm{mL}, 10 \mathrm{~min}$ ) (Merck KGaA, Darmstadt, Germany) at $37{ }^{\circ} \mathrm{C}$. To determine the inhibitory effect of PKG II on phosphorylation of the EGFR substrate, the reactions were carried out as described above, but with the addition of poly (Glu, Tyr) (500 nM, $20 \mathrm{~min}$ ) (Merck $\mathrm{KGaA}$ ), and the detailed steps, please refer to Thomas' paper [12]. At the end of the reaction, the mixture was heated for $5 \mathrm{~min}$ at $100{ }^{\circ} \mathrm{C}$ with an equal volume of pre-heated $2 \times$ sodium dodecyl sulfate sample buffer and then collected for WB analysis.

2.3.20 In vitro assay of recombinant PKG II-induced phosphorylation of the recombinant EGFR extracellular fragment

The reaction mixture, which included $20 \mu \mathrm{L}$ of in vitro reaction buffer (as described above), $570 \mathrm{nM}$ recombinant EGFR extracellular fragment (Sino Biological Inc, China), $150 \mathrm{nM}$ recombinant PKG II, and $400 \mu \mathrm{M}$ 8-pCPT-cGMP, was incubated at $37^{\circ} \mathrm{C}$ for $20 \mathrm{~min}$. Afterward, the samples were treated as described above and then collected for WB analysis.

\subsection{Statistical analysis}

The data were expressed as the mean \pm standard deviation. Statistical analyses were conducted using GraphPad Prism 8 software (GraphPad Software, Inc., San Diego, CA, USA). Differences among groups were detected using one-way analysis of variance with Tukey's multiple comparisons test. A probability ( $p$ ) value of $<0.05$ was considered statistically significant.

\section{Results}

\subsection{Secretion of PKG II is a physiological phenomenon related to gastric and colon cancer}

PKG II was first identified as a membrane-bound cGMP receptor in the intestinal epithelium. Interestingly, during the investigation of PKG II,we identified that the cells containing PKG II are similar with the intestinal endocrine cells of human and mouse (Fig. 1). This finding was especially interesting because it remained unclear whether PKG II was only present within endocrine cells or was actually secreted. Chromogranin A (CGA) is often used as a biomarker of enterochromaffin (EC) cells, which are the most common type of enteroendocrine cells in the gastrointestinal (GI) tract [15]. Based on the characteristics and location of these cells, the relationship between PKG II and chromogranin A was investigated. The confocal microscopy results showed that there is colocalization of PKG II and CGA in the same cell (Fig. 2A), hinting that PKG II might be secreted by EC cells and convey endocrinological activities. Furthermore, the results of immunoelectron microscopy confirmed that cells in GI tissues had secretory vesicles that contained CGA, while other secretory vesicles contained PKG II (Fig. 2B).

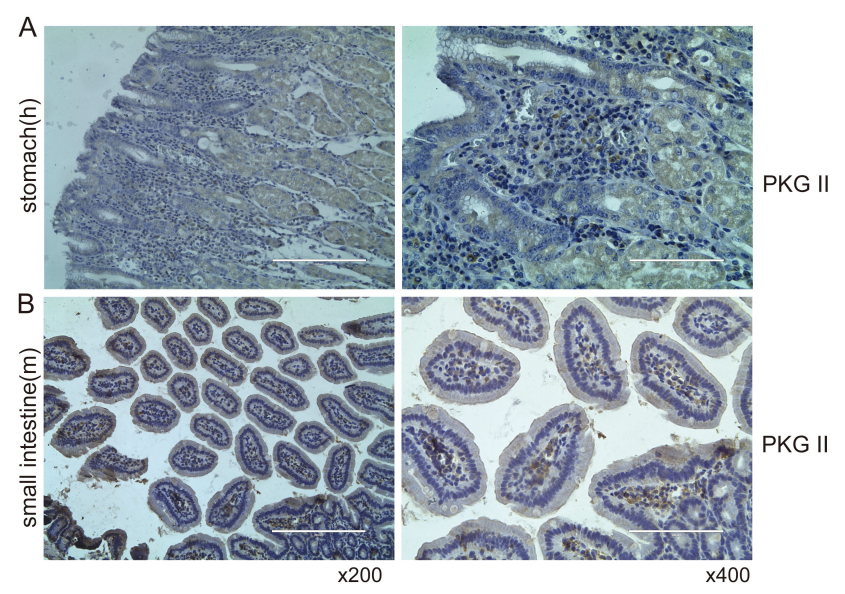

Fig. 1. PKG II is located in the GI tract. There were at least a group of cells containing high-level PKG II in the human and mouse gastrointestinal mucosal tissues by Immunohistochemistry.

PKG II was detected in the serum of healthy volunteers and cancer patients, but the levels were comparatively downregulated in the serum of patients with colon or gastric cancer $(754.1 \pm 173.9$ vs. $193.7 \pm 109.5$ and 230.0 $\pm 112.1 \mathrm{pg} / \mathrm{mL}$, respectively, $p<0.001$, Fig. 2C). Receiver operating characteristic (ROC) curve analysis was performed to further evaluate the utility of PKG II as a potential biomarker of cancer (Fig. 2D,E). For colon cancer, the sensitivity and specificity of PKG II were $95.38 \%$ and $100 \%$, respectively, at a cutoff value of $426.91 \mathrm{pg} / \mathrm{mL}$ with an area under the ROC curve (AUC) of 0.998 ( $\mathrm{Z}=160.513$, $p<0.001)$. For gastric cancer, the sensitivity and speci- 

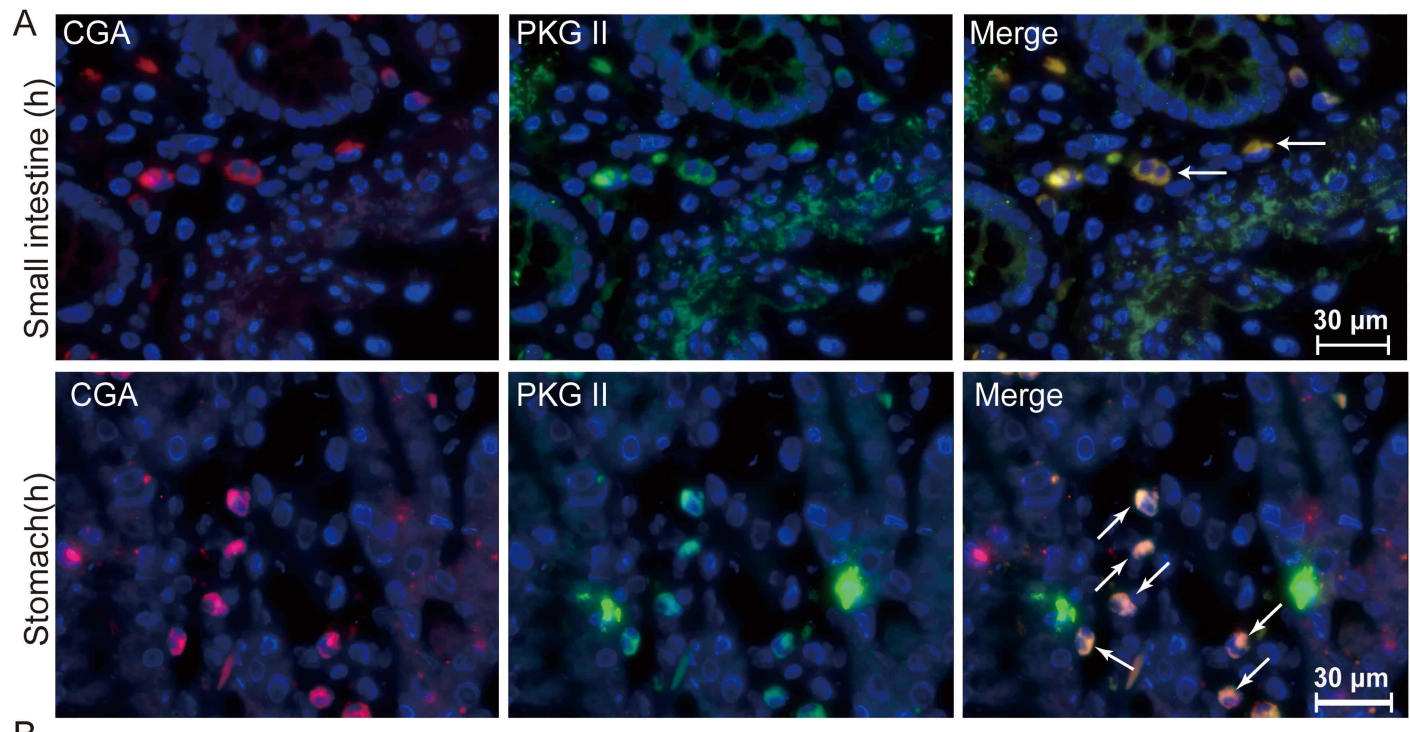

$\mathrm{B}$
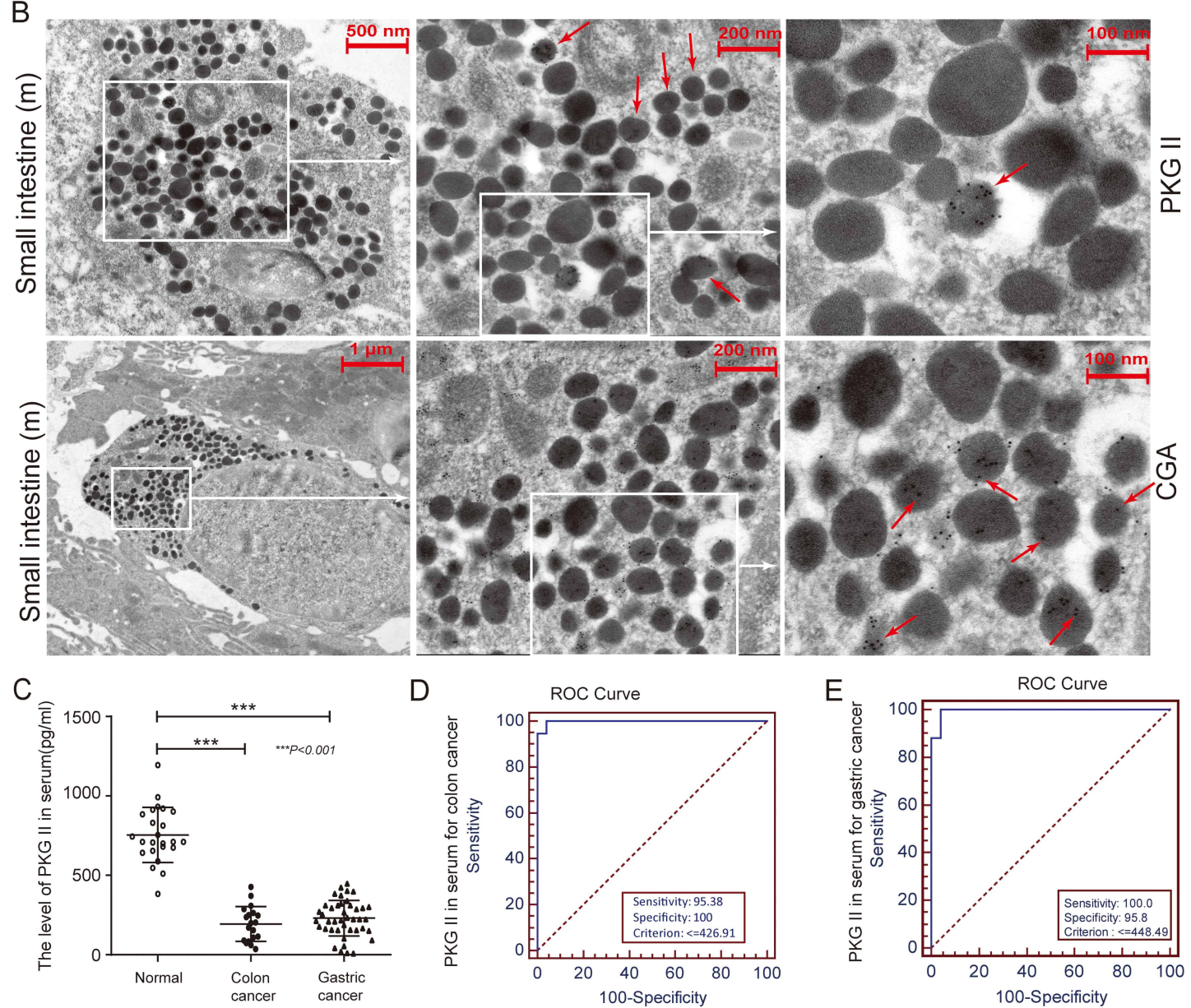

Fig. 2. The secretion of PKG II was a physiological phenomenon, and its secretion level was related to gastric and colon cancer. (A) Co-location of PKG II and Chromogranin A (CGA) was sporadically distributed cells in the gastrointestinal tract, detected by Confocal Microscopy. (B) The secretory vesicles of the cells contained PKG II (up panel) and CGA (bottom panel) were detected by ElectroMicroscopy, and the positively labeled vesicles were indicated by red arrows. (C) PKG II was detected in the serum of normal subjects $(\mathrm{n}=24)$; patients with colorectal $(\mathrm{n}=20)$ or gastric $(\mathrm{n}=42)$ cancer. All blood samples were taken from the patients before treatment, and PKG II in the serum samples were detected by the ELISA kit according to manufacturer's specifications. The levels represent the median \pm inter-quartile range ( \pm Q) of the PKG level. ***p $<0.001$ versus Normal. (D) ROC plots of PKG II level in colon cancer. (E) ROC plots of PKG II level in gastric cancer. h, human; m, mouse;ROC, receiver operator characteristic curve. 
ficity of PKG II were $100 \%$ and $95.8 \%$, respectively, at a cutoff value of $448.49 \mathrm{pg} / \mathrm{mL}$ with an AUC of 0.995 (Z $=91.854, p<0.001)$. These results indicated that serum PKG II was a potential diagnostic biomarker for gastric and colon cancer. To further clarify the potential secretion and mechanism of PKG II, cells with very low expression or lack of endogenous PKG II (i.e., GES-1, AGS, and HGC27 cells) were selected and infected with viral vectors encoding PKG II (Ad-PKG II) for 24-48 h. The results confirmed the presence of PKG II in the cell culture media (Fig. 3A). PKG II concentrations were also relatively increased in the serum of mice injected with Ad-PKG II $\left(10^{7}\right.$ plaque-forming units/mouse, once every two days, a total of 6 times) (Fig. 3B), showing that PKG II might be secreted into the blood circulation.
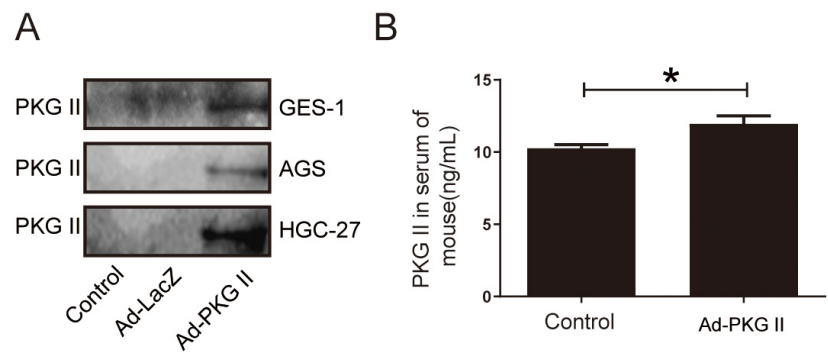

Fig. 3. PKG II was found in the culture medium of different cells and the blood from the mouse. (A) PKG II was detectable in the culture medium of gastric mucosal epithelial cell line GES1 and gastric cancer cell lines AGS and HGC-27 infected with the virus vector encoding cDNA of PKG II (Ad-PKG II) by ELISA assay. (B) Detection of PKG II in the serum of mouse and the concentration of PKG II was increased in the serum of the mouse injected with Ad-PKG II ( $10^{7} \mathrm{pfu} /$ mouse, once 2 days, 6 times in total) $* p<0.05$ versus Control.

\subsection{PKG II is secreted via the conventional secretory pathway}

As PKG II has no classical signal peptide, as predicted by the SignalP 6.0 Prediction Server (Fig. 4), PKG II might be secreted via a non-classical secretory pathway, such as the lysosome or exosome secretory pathway. But the Confocal Microscopy results showed that PKG II did not colocalize with lysosome-associated membrane protein-1 (LAMP1) (Fig. 5A) and the results of WB detection showed that PKG II was absent in the exosomes extracted from HGC-27 cells infected with Ad-PKG II (Fig. 5B). The above results indicated that PKG II was not secreted by lysosomes or the exosome secretory pathways. However, in Ad-PKG II-infected cells, PKG II was located surrounding the nucleus or accumulated in one side of the nucleus, similar to the location of the endoplasmic reticulum (ER) and Golgi (Fig. 5C, middle). Furthermore, Confocal Microscopy results showed that PKG II was co-localized with both glucose-6-phosphatase (G-6-Pase) and Golgi matrix protein $130 \mathrm{kD}$ (GM130), which were biomarkers of the ER and Golgi, respectively [16,17], indicating that PKG II was located in the ER and Golgi both in the cell lines and small intestine tissues (Fig. 5C,D). To further clarify that PKG II was indeed located within the ER cavity and not attached to the membrane surface, Co-IP was performed to detect the binding between PKG II and glucose-regulated protein 78 (GRP78), which acts as the master of the unfolded protein response process in the lumen of the ER [18] (Fig. 5E). Meanwhile, N-glycosylation of PKG II, an essential post-translational modification in the ER cavity, was also detected by enzymatic digestion [19] (Fig. 5F). The results showed that PKG II was not only bound to GRP78, but also N-glycosylated (Fig. 5E,F), confirming that PKG II was located within the ER cavity. PKG II was also detected in the Golgi Extract by WB (Fig. 5G). In addition, brefeldin A (BFA), an inhibitor of protein transport from the ER to Golgi [20], decreased the PKG II content in cell culture medium (Fig. 5H) and mouse serum (Fig. 5I). These results indicated that PKG II was likely secreted via the conventional ER-Golgi pathway [21].

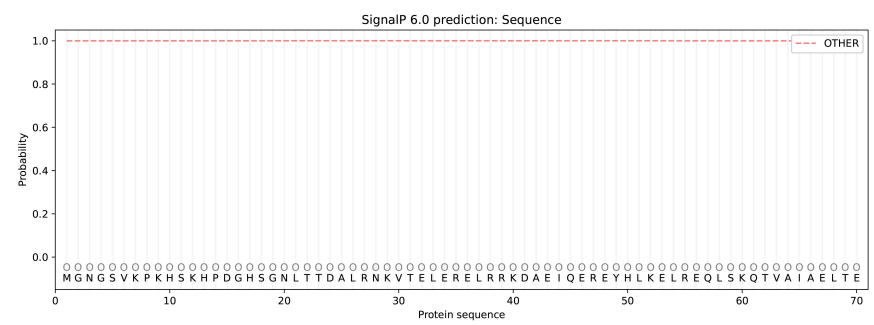

Fig. 4. Prediction of Signal peptide in PKG II-AA chain by SignalP-6.0. There was no signal peptide for PKG II.

3.3 Glycine 2 (G2) myristoylation and the N-terminus (aa 3-30) of PKG II are key to induce PKG II secretion via the ER- Golgi secretory pathway

The N-terminal signal peptide directs the newly synthesized aa chain to enter the ER cavity for secretion via the conventional protein secretory pathway [22]. However, PKG II has no signal peptide. Reportedly, N-terminal myristoylation is associated with anchoring of PKG II to the cellular membrane [23]. In this experiment, the results of Co-IP and confocal microscopy confirmed the binding and co-localization of PKG II and N-myristoyltransferase 1 (NMT1), which was an enzyme that regulates N-terminal myristoylation [24] (Fig. 6A,B). PKG II expression in mouse serum was downregulated by the NMT1 inhibitor DBA [25] (Fig. 6C), confirming the role of myristoylation modulation in the secretion of PKG II in vivo.

Myristoylation of PKG II occurs through modification of $\mathrm{G} 2$ by the covalent attachment of myristate, while mutation of $\mathrm{G} 2$ to alanine (G2A) blocks this modification 

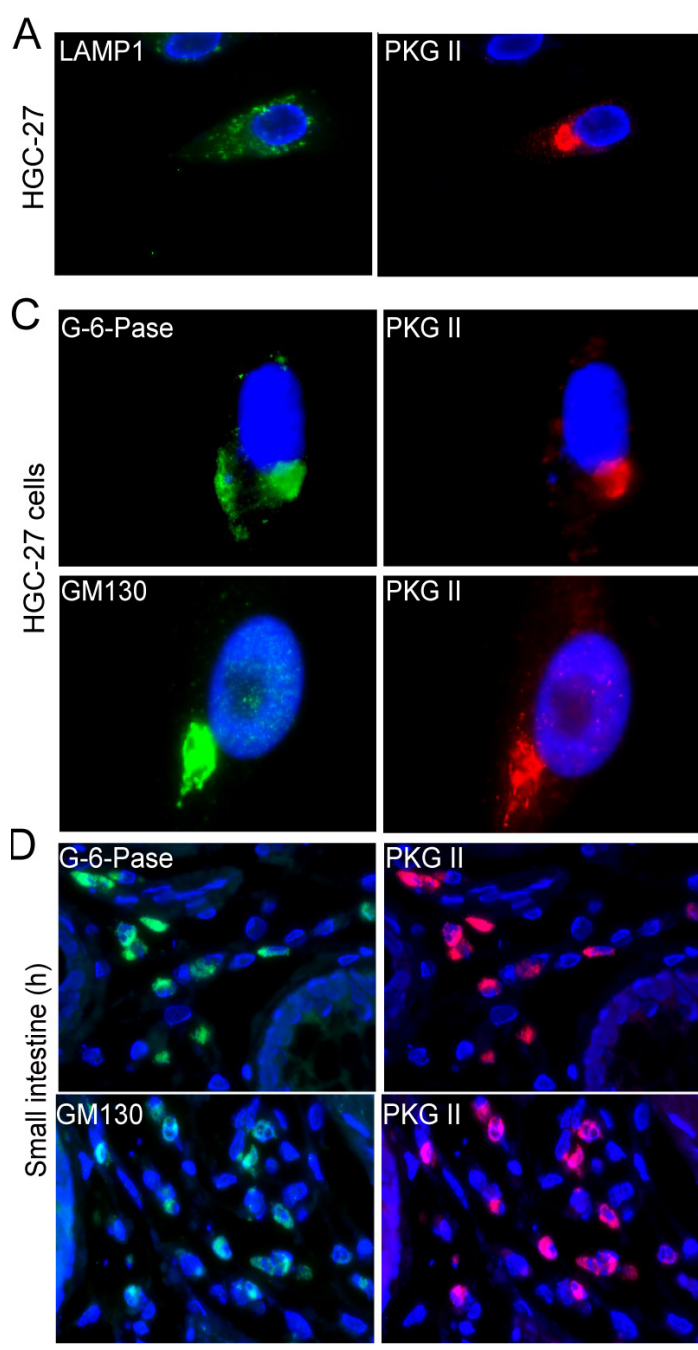

$\mathrm{H}$

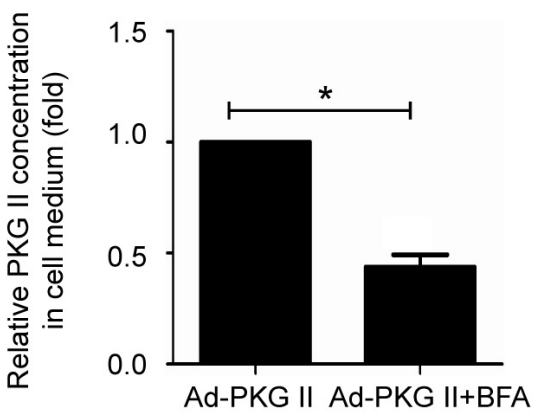

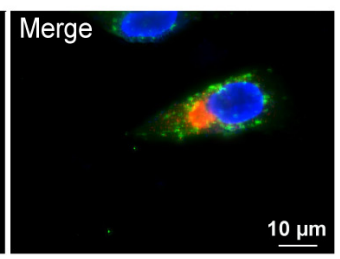

B

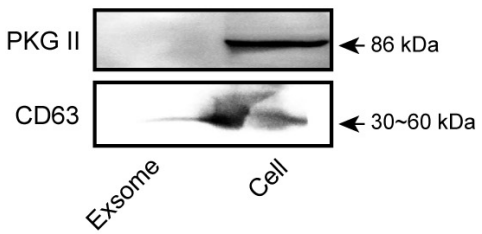

$E$
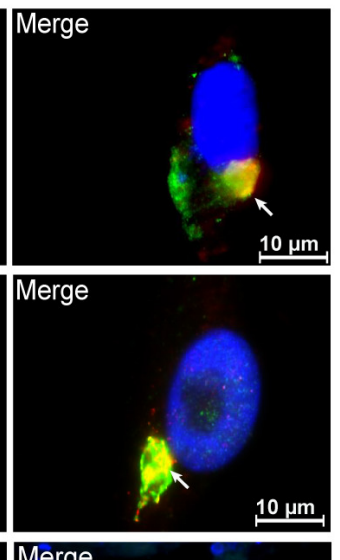

$|\mathrm{B}: P K G|$

IB:GRP78

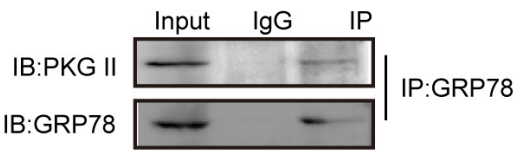
IP:PKG II

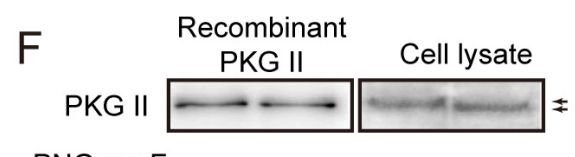

PNGase F $\quad-\quad+\quad+\quad-\quad+$ Ad-PKG II $\quad-\quad+\quad+$ GST-PKG II + + $\quad+\quad-$

G

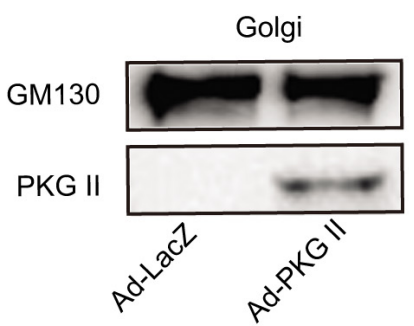

I

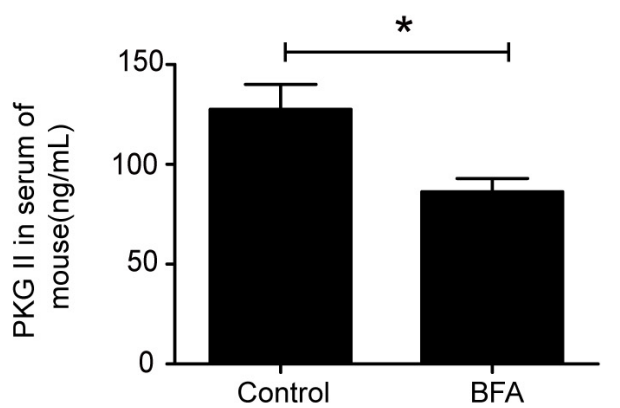

Fig. 5. PKG II could be secreted by the conventional secretion pathway. (A) The location of PKG II and LAMP1 (a biomarker of lysome) in the HGC-27 cells infected Ad-PKG II, detected by Confocal Microscopy. (B) The detection of PKG II in the exosomes by Western blotting. (C) Co-location of PKG II with G-6-Pase and GM130 in Ad-PKG II infected HGC-27 cells, detected by Confocal Microscopy. (D) Co-location of PKG II with G-6-Pase and GM130 in human small intestine tissue detected by Confocal Microscopy. (E) The binding of PKG II with GRP78, detected by Co-IP. (F) Evidence of N-glycosylation-modulation of PKG II. The molecular size of native PKG II but not recombinant GST-PKG II was decreased by PNGase F which could remove almost all N-linked oligosaccharides. (G) Location of PKG II in isolated Golgi apparatus, detected by Western blotting. (H) Result of ELISA assay showing the down-regulation of PKG II content in cell culture medium by ER-Golgi transport inhibitor Brefeldin A (BFA).HGC-27 cells were infected with Ad-PKG II for $24 \mathrm{~h}$ and treated with BFA $(50 \mathrm{ng} / \mathrm{mL})$ for another $24 \mathrm{~h}$. ( ${ }^{*} p<0.05$, compared with Ad-PKG II group). (I) Result of ELISA assay showing the down-regulation of PKG II in the serum samples collected from healthy female BALB/c mice intraperitoneally injected with $10 \mathrm{mg} / \mathrm{kg}$ of BFA for 3 days ( ${ }^{*} p<0.05$, compared with Control group). h, human; IP, immunoprecipitation; IB, immunoblotting/Western blotting. 

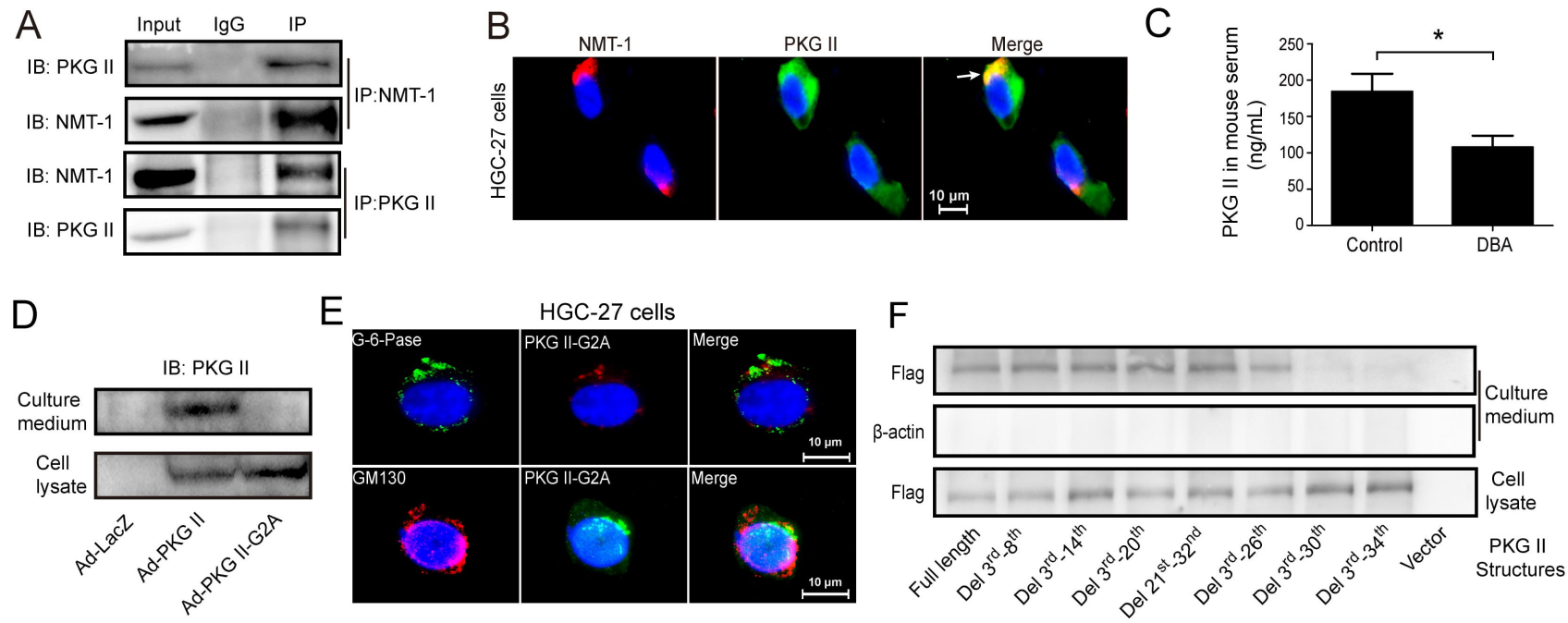

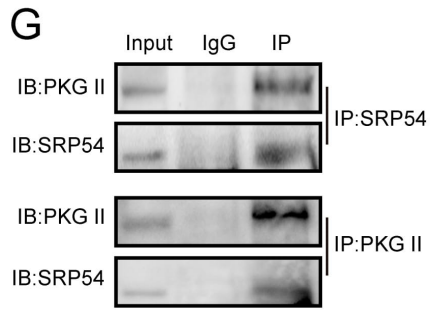

$J$

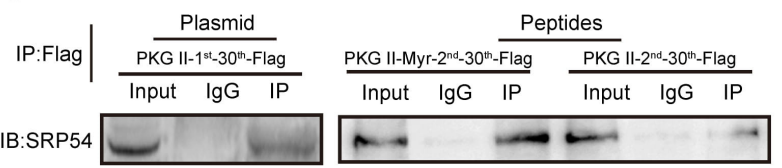

$\mathrm{H}$

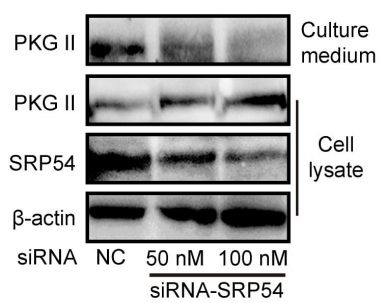

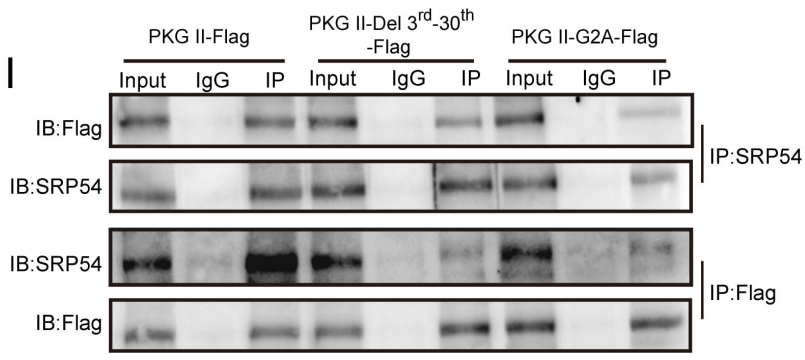

$\mathrm{K}$

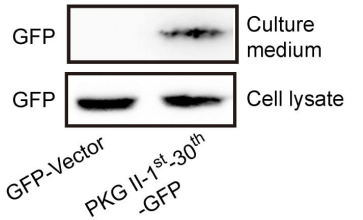

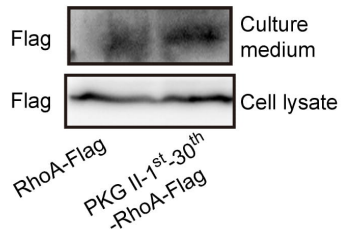

Fig. 6. Glycine 2 (G2) myristoylation and N-terminal peptide (3rd-30th aa) of PKG II were the key factors for inducing PKG II to enter the ER-Golgi secretion pathway. (A) The interaction between NMT1 and PKG II, detected by Co-IP. (B) Co-location between PKG II and NMT1 in HGC-27 cells infected with Ad-PKG II, detected by Confocal Microscopy. (C) Detection of PKG II in mouse serum and the content was decreased by treatment with NMT1 inhibitor DBA (40 mg/kg, once every 3 days, 6 times in total). $\left({ }^{*} p<\right.$ 0.05, compared with the Control group). (D) Western blotting results showing the decrease of PKG II secretion in cultured cells induced by G2 mutation (PKG II-G2A). (E) Confocal Microscopy results showing that PKG II mutated at G2 (PKG II-G2A) were not co-located with G-6-Pase and GM130. (F) The effects of different deletions of PKG II on its secretion. (G) The interaction between SRP54 and PKG II, detected by Co-IP. (H) The decrease of PKG II secretion in Ad-PKG II infected cells caused by siRNA-induced down-regulation of SRP54, detected by Western blotting. NC: negative control. (I) Co-IP was applied to detect the interaction between SRP54 and PKG II in the cells transfected with the different plasmids coding PKG II-Flag, PKG II-Del 3rd-30th-Flag or PKG II-G2A-Flag, respectively. (J) Inhibition of the binding between SRP54 and PKG II when there is only 2-30 aa without G2 myristoylation (PKG II-2nd-30th Flag peptides), compared with the PKG II -1 st-30th-Flag and PKG II-Myr-2nd-30th Flag groups. (K) Western blotting was applied to detect the secretion of the non-secretory proteins GFP and RhoA induced by the 1st-30th aa of PKG II.

[23]. The results of this experiment showed that PKG II was not detected in the cell culture medium and had no longer co-localized with G-6-Pase and GM130 in cells with the nonmyristoylated PKG II mutant (G2A) (Fig. 6D,E), demonstrating that PKG II secretion was dependent on G2 myristoylation. Considering that not all G2 myristoylationmodulated proteins were secreted, we inferred that other key aa residues might induce PKG II to enter the ER.
Thus, several truncated forms of PKG II were constructed [i.e., PKG II-Del(3-8), Del(3-14), Del(3-20), Del(3-26), $\operatorname{Del}(3-30)$, Del(3-34), and $\operatorname{Del}(21-32)]$. Notably, most of these truncated forms [i.e., $\operatorname{Del}(3-8), \operatorname{Del}(3-14), \operatorname{Del}(3-$ 20), Del(3-26), and Del(21-32)] had no obvious effect on the secretion of PKG II. However, the truncated forms $\operatorname{Del}(3-30)$ and Del(3-34) abolished the secretion of PKG II (Fig. 6F), confirming that aa 3-30 were important for secre- 
A

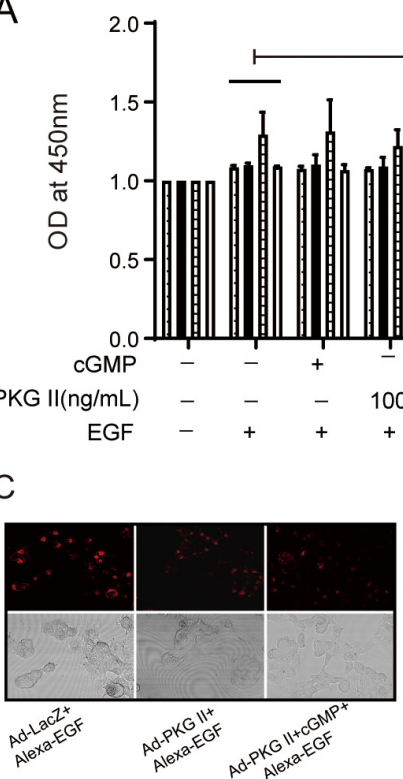

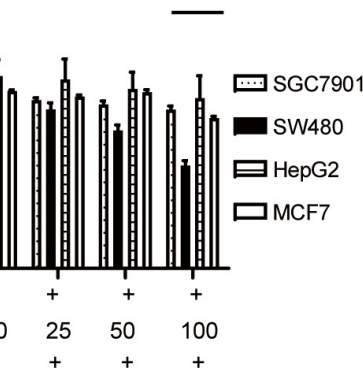

B

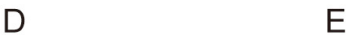

G
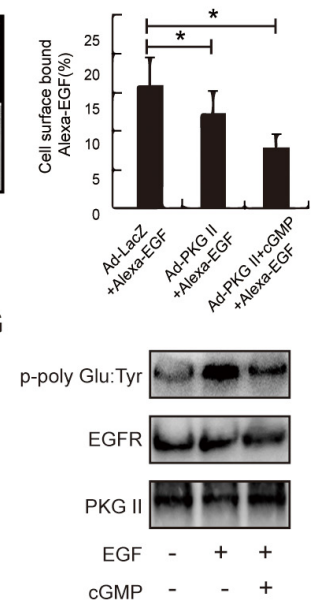

$\mathrm{E}$
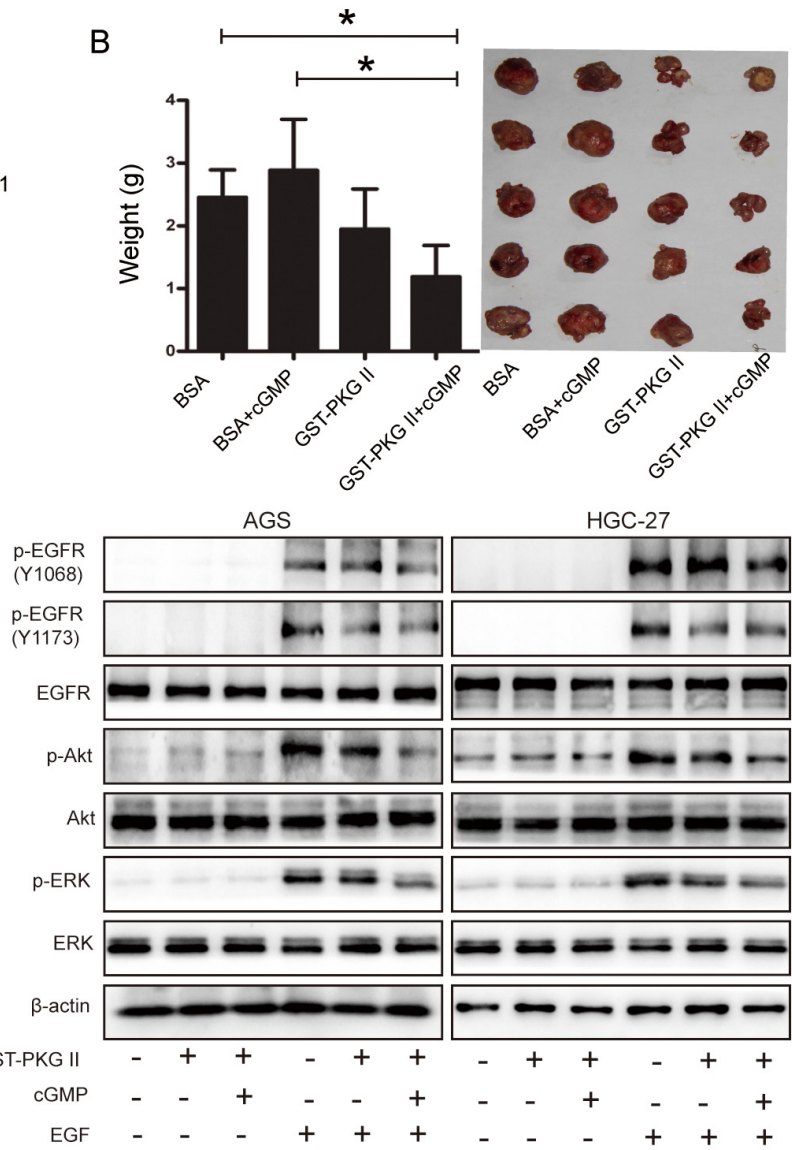

Fig. 7. The secreted PKG II could block the EGF-induced activation of EGFR. (A) SGC-7901, SW480, MCF-7, and HepG2 cells were respectively seeded in 96-well plates for $24 \mathrm{~h}$. After serum-starved for $12 \mathrm{~h}$, the cells were incubated with recombinant PKG II at indicated concentrations and treated with/without $250 \mu \mathrm{M}$ 8-pCPT-cGMP to active it for $1 \mathrm{~h}$ before the incubation with $100 \mathrm{ng} / \mathrm{mL}$ EGF for $24 \mathrm{~h}$. The proliferation activity of cells was analyzed with CCK-8 assay. The results showed that high concentration recombinant PKG II significantly inhibited the proliferation of the cells $\left({ }^{*} p<0.05\right)$. The data shown were the means $\pm \mathrm{SD}$ from 3 independent experiments. (B) In the transplantation tumor model of the nude mouse, administration of active recombinant PKG II plus 8-pCPT-cGMP inhibited the growth of transplantation tumors $\left({ }^{*} p<0.05\right.$ ); the BSA (bovine serum) albumin group serve as the control group. (C,D) COS-7 cells were infected with Ad-PKG II, treated with 8-pCPT-cGMP, and then incubated with Alexa Fluor 555-labeled EGF (100 ng/mL, $1 \mathrm{~h})$. The Cytometry and Fluorescent Confocal Microscopy were applied to detect the binding between EGF and EGFR $\left({ }^{*} p<0.05\right)$. (E) AGS and HGC-27 cells were treated with recombinant GST-PKG II (100 ng/mL) and 8-pCPT-cGMP $(250 \mu \mathrm{M})$ for $3 \mathrm{~h}$, and then with $100 \mathrm{ng} / \mathrm{mL}$ EGF for $10 \mathrm{~min}$. Western blotting was applied to detect phosphorylation of EGFR (Y1068 and Y1173), p-Akt (T308), and p-ERK (T202/Y204). The image was representative of three independent experiments. (F) Recombinant PKG II inhibited Y1068 phosphorylation of isolated EGFR. The AGS cells were cultured for $24 \mathrm{~h}$, serum-starved for $12 \mathrm{~h}$, and the cytomembrane was isolated and incubated with $150 \mathrm{nM}$ recombinant PKG II and with/without $400 \mu \mathrm{M}$ 8-pCPT-cGMP for $20 \mathrm{~min}$, and then with/without $4 \mu \mathrm{g} / \mathrm{mL}$ EGF for 10 min. The reaction mixtures were detected by Western blotting. (G) Recombinant PKG II inhibited the EGFR-induced tyrosine phosphorylation of poly (Glu, Tyr). The experiment procedure was similar as Fig. 7F except that $500 \mathrm{nM}$ poly (Glu, Tyr) was added at last and incubated for $20 \mathrm{~min}$. Western blotting with antibody against p-Tyr was performed to detect the tyrosine phosphorylation of poly (Glu, Tyr)

tion of PKG II. These results indicated that both G2 myristoylation and aa 3-30 were key factors for the secretion of PKG II via the conventional secretory pathway.

To further clarify the mechanism underlying the entry of PKG II into the ER, the relationship between PKG II and signal recognition particle 54 (SRP54) was investigated. SRP54 is key to inducing newly synthesized pep- tides/aa chains to enter the ER [26]. The Co-IP results showed that PKG II could bind with SRP54 (Fig. 6G) and PKG II secretion was decreased by silencing of SRP54 with siRNA (Fig. 6H). The Co-IP results showed that binding between SRP54 and PKG II was decreased by both G2 mutation (PKG II-G2A-Flag plasmid) and deletion of aa 3-30 (PKG II-Del 3rd-30th-Flag plasmid) (Fig. 6I). Fur- 
thermore, there is binding for PKG II and SRP54 both in the cell-tansfected with plasmid coding 1-30 of PKG II (PKG II-1st-30th-Flag) or the synthesized peptides containing aa 2-30 with G2 myristoylation (PKG II-Myr-2nd-30thFlag), but the binding is decreased when there is only $2-30$ aa without G2 myristoylation (PKG II-2nd-30th-Flag peptides) (Fig. 6J). Finally, Therefore, it appeared that both G2 myristoylation and the sequence of aa 3-30 acted as a "signal peptide" to induce newly synthesized PKG II-aa modified to enter the ER by binding with SRP54. Finally, insertion of aa 1-30 of PKG II into the non-secretory proteins GFP and RhoA promoted secretion of the corresponding proteins (Fig. 6K), further confirming the above mechanism of secretion.

\subsection{Secreted PKG II can block EGF-induced activation of EGFR}

To determine the extracellular function of PKG II, recombinant PKG II was used to imitate secreted PKG II. In vitro, the results of the CCK-8 assay showed that recombinant PKG II significantly inhibited EGF-trigged proliferation of multiple types of cancer cells (Fig. 7A). In vivo, recombinant PKG II with 8-pCPT-cGMP significantly inhibited the growth of transplanted tumor cells (Fig. 7B), indicating that PKG II plays an anti-cancer role upon secretion. Furthermore, recombinant PKG II was found to block the binding of fluorescently labeled EGF to EGFR, which happened on the outside of the membrane (Fig. 7C,D).

To further confirm the extracellular function of PKG II, recombinant PKG II was added to the culture medium of AGS and HGC-27 cells and its inhibitory effect on EGFR was assessed by WB analysis. The WB results showed that the EGF-induced phosphorylation of EGFR, ERK, and Akt were decreased by pretreatment with recombinant PKG II plus 8-pCPT-cGMP for $1 \mathrm{~h}$ (Fig. 7E). Meanwhile, the results of an in vitro reaction system showed that incubation of the isolated membranes with recombinant PKG II plus 8-pCPT-cGMP inhibited EGF-stimulated phosphorylation of EGFR-Y1068 (Fig. 7F). Furthermore, the isolated membrane reaction system with the use of poly (Glu, Tyr) as a substrate to detect EGFR activity [27] revealed that recombinant PKG II also inhibited EGF-induced phosphorylation of the tyrosine residue of the Glu/Tyr polymer (Fig. 7G), indicating that secreted PKG II could block EGF-induced tyrosine phosphorylation/activation of EGFR.

\subsection{Secreted PKG II phosphorylates T406 on the extracellular fragment of EGFR}

To further investigate the interaction between PKG II and EGFR, prokaryotic expression vectors encoding for different domain segments EGFR or PKG II were constructed. The results of the pull-down assay showed that the PKG II bound to the fragment containing aa 331-645 of the extracellular domain of EGFR (Fig. 8A,C). Meanwhile, the results also confirmed that the fragments containing aa $1-$
176 and 1-285 of PKG II bound to EGFR (Fig. 8B,D). The above results showed that PKG II could act on EGFR from the outside of the cell, thereby serving as a secretory protein kinase. Therefore, the His-tagged recombinant extracellular fragment of EGFR was incubated with recombinant GST-tagged PKG II in the in vitro reaction system. The results showed the Ser/Thr phosphorylation of the EGFR fragment was increased in the presence of recombinant PKG II (Fig. 8E, left), and that recombinant PKG II bound to the extracellular fragment of EGFR (Fig. 8E, right), indicating that recombinant $\mathrm{PKG}$ II could induce Ser/Thr phosphorylation of the recombinant extracellular fragment of EGFR.

The Group-based Prediction System (version 2.1) [28] predicted that threonine 406 (T406), threonine 727 (T727), and serine 945 (S945) were potential PKG II-specific phosphorylation sites of EGFR. Hence, various mutants of EGFR (i.e., T406P, T727P, and S945P) were constructed using a Site-Directed Mutagenesis Kit with the plasmid pcDNA3.1-Flag-EGFR. COS-7 cells were transfected with the corresponding plasmids and the mutant EGFRs expressed by the cells were isolated by Co-IP and then incubated with recombinant PKG II plus 8-pCPT-cGMP in an in vitro reaction mixture. The results showed that the mutations of T727P and S945P had no effect on phosphorylation of Ser/Thr of EGFR. However, the mutation of T406P decreased PKG II-induced Ser/Thr phosphorylation of EGFR (Fig. 8F). Besides, recombinant PKG II inhibited EGF-induced phosphorylation of Tyr1068/Tyr1173 of the T727P and S945P mutants, but not the T406P mutant (Fig. 8G), indicating that T406 was the key site which was phosphorylated by secreted PKG II to block the activation of EGFR.

\section{Discussion}

Most protein kinases are located within the cell bound to the membrane or distributed within the cytoplasm. However, some protein kinases were recently found to be secreted the outside of the cell via different protein secretory pathways in order to phosphorylate extracellular proteins [29-31]. Research on the phosphorylation of extracellular proteins has been ongoing for more than 100 years [32]. Recently, Klement et al. reported that phosphorylation of extracellular proteins was an important modification with potentially important biological significance [33]. However, the protein kinases responsible for phosphorylation of extracellular proteins remained unclear. Starting in about the year 2012, several studies identified that several kinases (i.e., family with sequence similarity 20 , member C, vertebrate lonesome kinase, and pyruvate kinase isozyme M2) were secreted to the outside of the cell for phosphorylation of extracellular proteins [29-31,34], thereby representing a new era of research on the phosphorylation of extracellular proteins. 
A

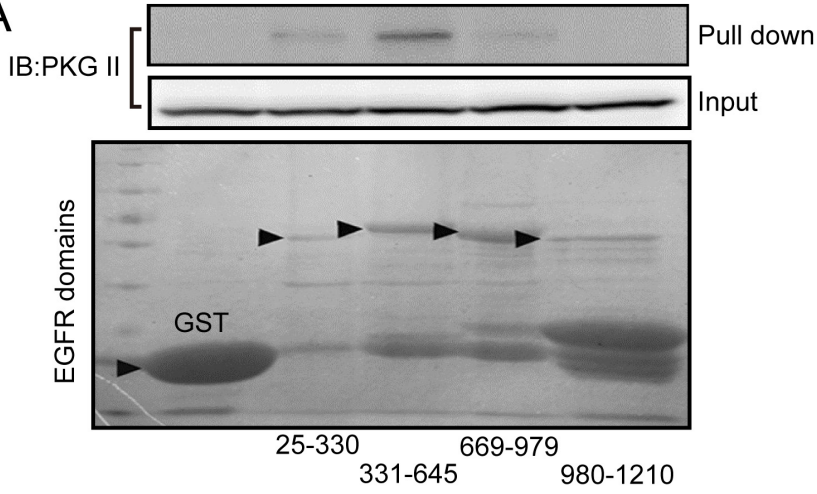

B

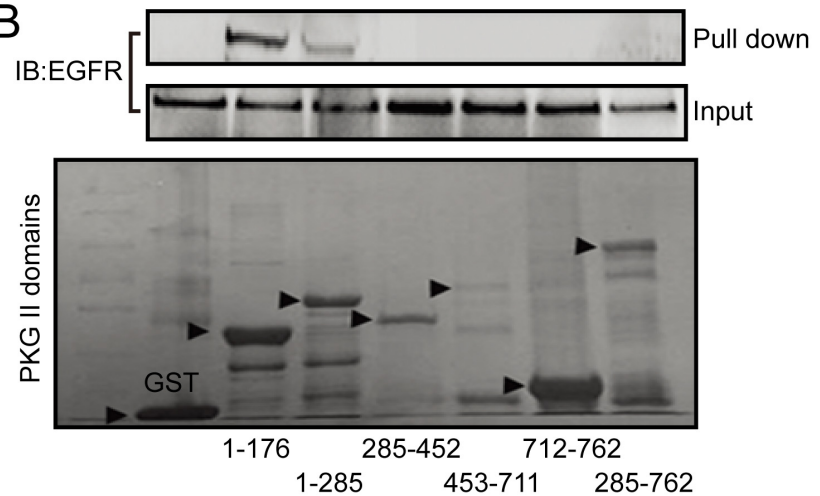

$\mathrm{F}$

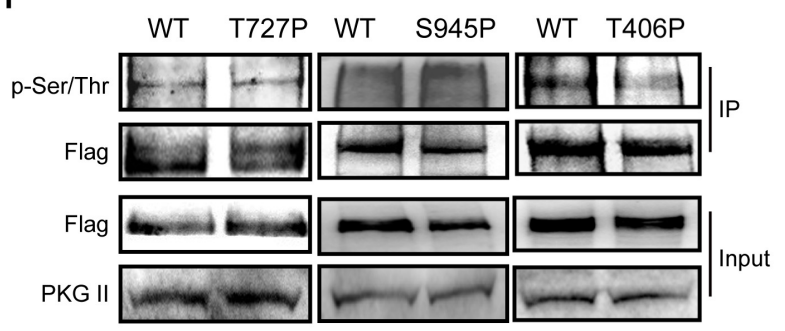

C

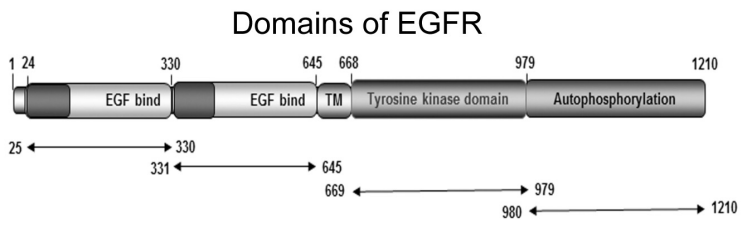

D

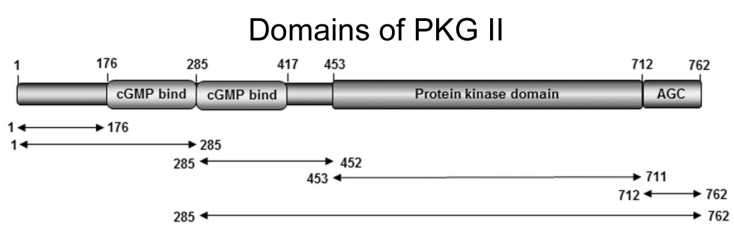

E

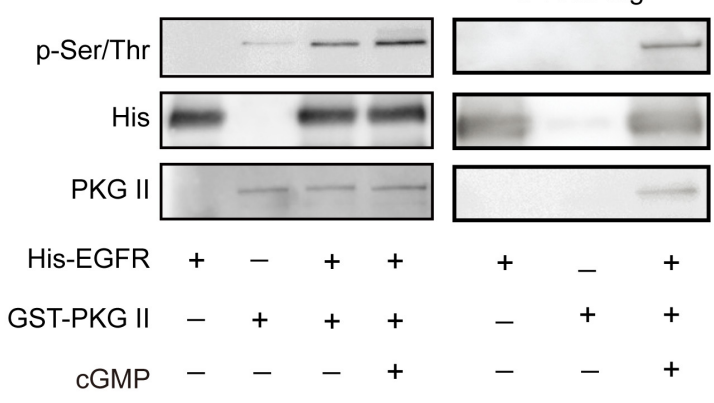

G

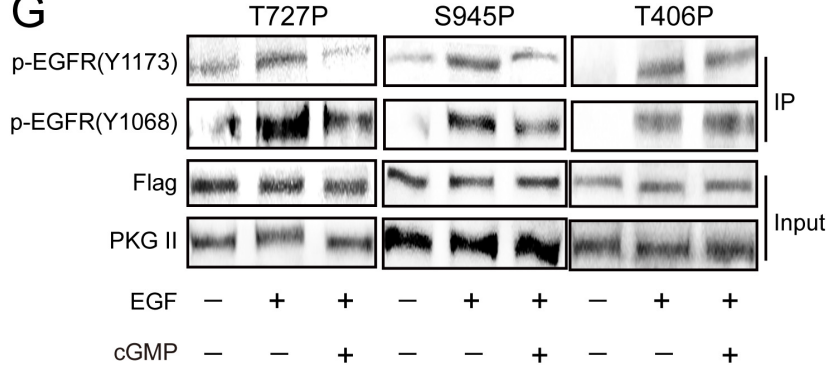

Fig. 8. The secreted PKG II could bind with EGFR and induced the phosphorylation of T406 on EGFR. (A,B) Identification of the binding domains of EGFR and PKG II. The prokaryotic expression vectors coding cDNA of different fragments of EGFR and PKG II were constructed, and the fragments were expressed in E. coli. The Pull-down method was applied for detecting the binding between different fragments of PKG II and EGFR in vitro. (C) Schematic of EGFR fragments/domains. (D) Schematic of PKG II fragments/domains. (E) Recombinant PKG II increased the p-Ser/Thr of a recombinant extracellular fragment of EGFR through binding with the fragment in vitro. The reaction mixtures included $570 \mathrm{nM}$ His-extracellular fragment (1-645aa) of EGFR (His-EGFR), $150 \mathrm{nM}$ GST-PKG II or $400 \mu \mathrm{M} 8$-pCPT-cGMP respectively. The reaction mixtures were also immuno-precipitated with the antibody against His tag, and the precipitates were subjected to Western blotting with antibody against pan phosphorylation of Ser/Thr (p-Ser/Thr) (the right). The results showed that PKG II could bound with and caused Ser/Thr phosphorylation of His-EGFR in vitro. (F) COS-7 cells were transfected with WT-EGFR, T727P-EGFR, S945P-EGFR, and T406P-EGFR plasmids respectively for $24 \mathrm{~h}$. On the 2nd day after transfection, the cells were infected with Ad-PKG II for $12 \mathrm{~h}$ and then serum-starved for another $12 \mathrm{~h}$. After that, the cells were treated with 8-pCPT-cGMP $(250 \mu \mathrm{M})$ for $1 \mathrm{~h}$. The lysates were harvest and immuno-precipitated with anti-Flag antibody to enrich the mutant EGFR proteins. Western blotting was used to detect the p-ser/thr phosphorylation of these mutants of EGFR. (G) COS-7 cells were transfected with corresponding plasmids respectively for $24 \mathrm{~h}$. On the 2nd day, the cells were infected with Ad-PKG II for $12 \mathrm{~h}$ and then serum-starved for another $12 \mathrm{~h}$. After that, the cells were treated with 8-pCPT-cGMP $(250 \mu \mathrm{M})$ for $1 \mathrm{~h}$ and subsequently incubated with EGF $(100 \mathrm{ng} / \mathrm{mL})$ for $10 \mathrm{~min}$. The lysates were immuno-precipitated with anti-Flag antibody. The precipitates were suspended with $100 \mu \mathrm{L}$ reaction mixture. The supernatants were equally divided into three groups which contained $150 \mathrm{nM}$ PKG II, $150 \mathrm{nM}$ PKG II $+400 \mu \mathrm{M}$ 8-pCPT-cGMP (incubation for $20 \mathrm{~min}$ to activate PKG II), and $150 \mathrm{nM}$ PKG II $+400 \mu \mathrm{M}$ 8-pCPT-cGMP $+4 \mu \mathrm{g} / \mathrm{mL}$ EGF (incubation for $10 \mathrm{~min}$ ). The mixtures were detected by Western blotting with anti-p-Tyr1068(Y1068) and p-Tyr1173(Y1173) antibodies. The results were representative of three independent experiments. 


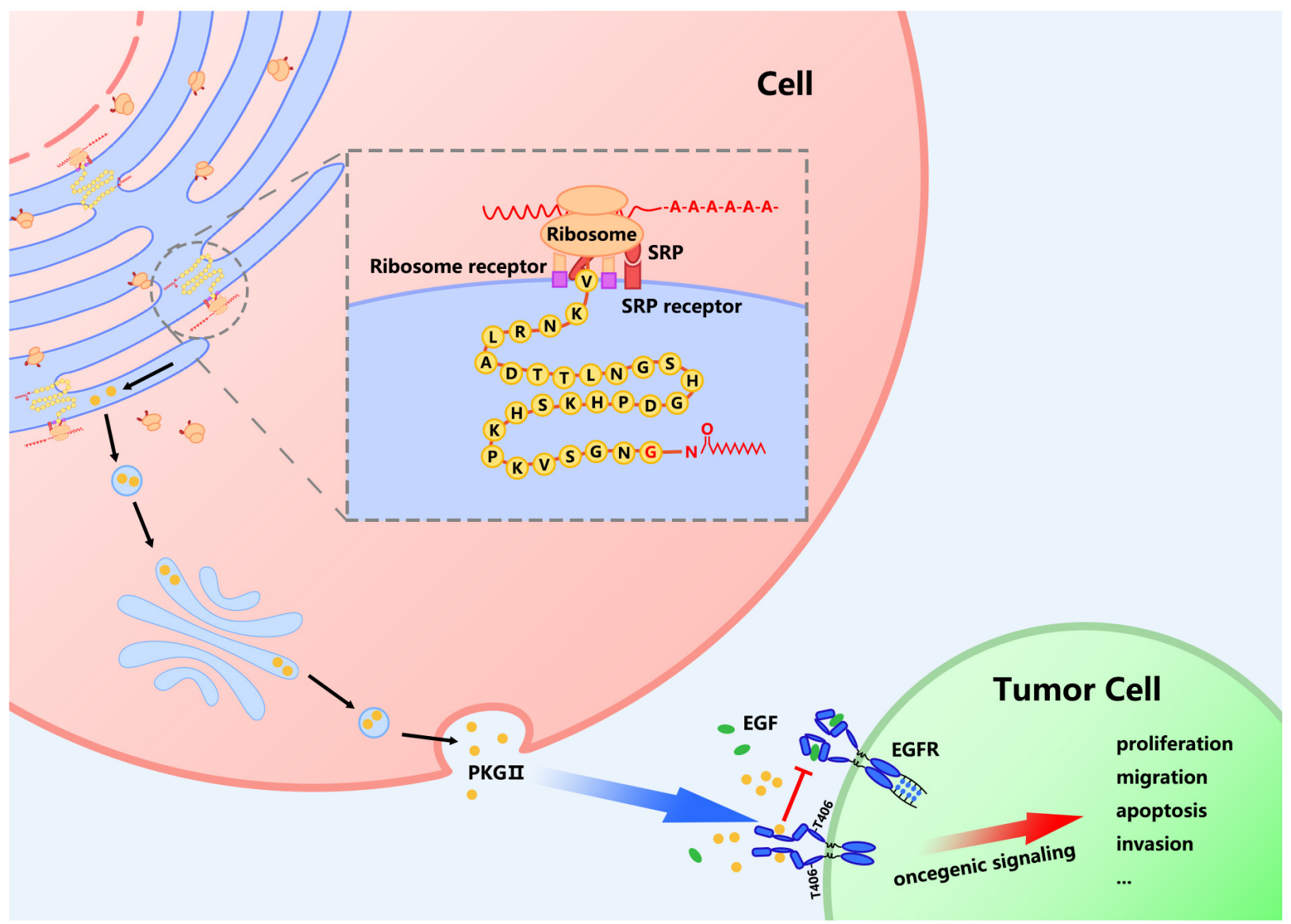

Fig. 9. Schematic diagram of PKGII secretion and targets.

PKG II was first described in 1983 as an intracellular membrane-bound serine/threonine protein kinase $[2,3,35]$. In the present study, PKG II was detected in cell culture medium as well as the serum of healthy volunteers with lower concentrations in the serum of cancer patients. These findings present convincing evidence that PKG II is also a secreted protein kinase. Most proteins are secreted via the conventional protein secretory pathway. However, proteins which are secreted via this pathway usually have an $\mathrm{N}$ terminal signal peptide composed of 15-30 a that can bind with SRP54 and the SRP54 receptor to direct newly synthesized aa chains to enter the ER for synthesis and then mature in the GA, prior to secretion via secretory vesicles [21]. However, this theory cannot explain the secretion of all proteins because those without signal peptides might be secreted via the unconventional protein secretory pathway $[36,37]$.

Since PKG II has no signal peptide, the origin and the mechanism underlying the secretion of PKG II remain unclear. Usually, the core of the signal peptide contains a long stretch of about 5-16 hydrophobic aa residues [38], which is absent in PKG II. However, the second aa of the PKG II chain is a glycine residue, which can undergo myristoylation to increase the hydrophobicity of the N-terminus [23]. Myristoylation is the NMT-mediated modulation on the N- terminal glycine in the aa chain [24]. Previous studies have shown that myristoylation also regulates the intracellular location and the secretion of some proteins. For example, myristoylated adenylate kinase 2 of the protozoan Plasmodium falciparum can penetrate the plasma membrane and move to the outside of the cell [39]. In addition, secretion of extracellular protein kinase A by tumor cells is inhibited by NMT [40], while myristoylation promotes the translocation of protein kinase $\mathrm{C}$ in human and animal serum across the cell membrane $[41,42]$. Therefore, the ability of N-terminal myristoylation to induce PKG II to enter the ER- GA secretory pathway was investigated and the results confirmed that G2 myristoylation was closely related to the secretion of PKG II.

The prevalence of proteins with a myristoylated $\mathrm{N}$ terminus in eukaryotes is estimated at $0.5-3 \%$ of the cellular proteome, depending on the species and predictive model $[43,44]$. This study is the first to show that the N-terminale myristoylated protein without a signal peptide can be secreted via the conventional secretory pathway. So, there must be other factors regulating the secretion, such as the aa sequence of PKG II. In this study, truncation of the aa sequence confirmed that aa 3-30 were necessary for the secretion of PKG II, suggesting that myristoylation of G2 and aa 3-30 acted as a "signal peptide" to induce the secretion of 
PKG II. This finding also provided a clue about the mechanism underlying the secretion of other proteins without signal peptides.

Another interesting finding was that PKG II was secreted by EC cells, which were important components of the enteroendocrine cell system in the GI tract, and could secrete/release more than one GI hormone or peptide [45]. EC cells were a subset of chromaffin cells that contained many vesicles stained by potassium dichromate $[46,47]$ and were first discovered in the adrenal medulla [48]. Later, EC cells were also found in the GI tract and could secrete 5-hydroxytryptaphane (serotonin), cholecystokinin, and secretin [49], which regulated the motility of the GI tract [50]. The results of this study confirmed that PKG II was secreted by EC cells, indicating a potential correlation between the endocrine system and the secretion of protein kinases. Further investigations of the effects and targets of the secreted PKG II confirmed that the N-terminus of PKG II (aa 1176) bound to the $\mathrm{C}$-terminus of the extracellular fragment of EGFR (aa 331-645), blocking the activation of EGFR through phosphoralyting its T406.

\section{Conclusions}

In summary, this study confirmed that PKG II was secreted by the EC cells in gastrointestinal mucose via the conventional protein secretory pathway without the present of typical "signal peptide" which was required for the secretion, and the myristoylated G2 and aa 3-30 of the amino acid chain of PKG II acted as a "signal peptide" to initiate the secretion of the kinase (Fig. 9). These results revealed a new protein secretion pattern and a correlation between the endocrine system and the secretion of protein kinases. It was also confirmed that the level of secreted PKG II in blood was related to tumogenesis and the secreted PKG II could block the activation of EGFR through phosphoralyting its therione 406 and inhibit the growth of tumor cells. Our results not only confirmed the phenomenon and mechanism of PKG II, but also affirmed that secreted PKG II has an anti-cancer effect and might be useful for the diagnosis of colon and gastric cancer, indicating that detection of PKG II in the blood and body fluids, similar with hormones, is predictive of tumorigenesis.

\section{Abbreviations}

PKG II, Protein kinase G type II; EC, enterochromaffin; EGF, epidermal growth factor; CGMP, cyclic guanosine monophosphate; EGFR, epidermal growth factor receptor; WB, Western blot; BSA, bovine serum albumin; Co-IP, Co-immunoprecipitation; GA, Golgi apparatus; ELISA, enzyme-linked immunosorbent assay; siRNAs, Short-interfering RNAs; GI, gastrointestinal; ROC, Receiver operating characteristic; ER, endoplasmic reticulum; NMT1, N-myristoyl-transferase 1; SRP, signal recognition particle.

\section{Author contributions}

YW and YCC designed the research study. MW, ZBW, JP, MLZ, TL, XYY, HQ, and YJZ performed the research. XYL, LJ, YT provided help and advice on the research. MW and TL analyzed the data. YW and YCC wrote the manuscript. All authors contributed to editorial changes in the manuscript. All authors read and approved the final manuscript.

\section{Ethics approval and consent to participate}

Studies involving animals include a statement on ethics approval. The study protocol involving human subjects was approved by the Medical Ethics Committee of Jiangsu University and written informed consent was obtained from each subject prior to participation in this study (attached in the Supplementary materials). Animal license number: SYXK(Su)-2013-0036.

\section{Acknowledgment}

We thank LetPub (www.letpub.com) for linguistic assistance and pre-submission expert review. And we also thank Gerry Boss and Renate Pilz of the University of California (San Diego, CA, USA) for providing the adenoviral constructs.

\section{Funding}

This study was supported by grants from the National Natural Science Foundation of China (grant number 31771564 and 81201959); the Natural science fund for colleges and universities in Jiangsu Province (grant number 17KJB310001); Funding from the Health and Health Commission of Jiangsu Province (grant number LGY2018025); "333 project" scientific research project (grant number BRA2019172).

\section{Conflict of interest}

The authors declare no conflict of interest.

\section{Supplementary material}

Supplementary material associated with this article can be found, in the online version, at https://www.imrpre ss.com/journal/FBL/27/2/10.31083/j.fbl2702053.

\section{References}

[1] Ceramella J, Iacopetta D, Barbarossa A, Caruso A, Grande F, Bonomo MG, et al. Carbazole Derivatives as Kinase-Targeting Inhibitors for Cancer Treatment. Mini-Reviews in Medicinal Chemistry. 2020; 20: 444-465.

[2] de Jonge HR. Cyclic GMP-dependent protein kinase in intestinal brushborders. Advances in Cyclic Nucleotide Research. 1981; 14: 315-333.

[3] Vaandrager AB, Ehlert EM, Jarchau T, Lohmann SM, de Jonge HR. N-terminal Myristoylation is Required for Membrane Localization of cGMP-dependent Protein Kinase Type II. Journal of Biological Chemistry. 1996; 271: 7025-7029. 
[4] Wincott CM, Abera S, Vunck SA, Tirko N, Choi Y, Titcombe $\mathrm{RF}$, et al. cGMP-dependent protein kinase type II knockout mice exhibit working memory impairments, decreased repetitive behavior, and increased anxiety-like traits. Neurobiology of Learning and Memory. 2014; 114: 32-39.

[5] Nie HG, Chen L, Han DY, Li J, Song WF, Wei SP, et al. Regulation of epithelial sodium channels by cGMP/PKGII. The Journal of Physiology. 2009; 587: 2663-2676.

[6] YUASA K, UEHARA S, NAGAHAMA M, TSUJI A. Transcriptional Regulation of cGMP-Dependent Protein Kinase II (cGK-II) in Chondrocytes. Bioscience, Biotechnology, and Biochemistry. 2010; 74: 44-49.

[7] Chen J, Zhang H, Zhang X, Yang G, Lu L, Lu X, et al. Epithelial sodium channel enhanced osteogenesis via cGMP/PKGII/ENaC signaling in rat osteoblast. Molecular Biology Reports. 2014; 41: 2161-2169.

[8] Swartling FJ, Ferletta M, Kastemar M, Weiss WA, Westermark B. Cyclic GMP-dependent protein kinase II inhibits cell proliferation, Sox9 expression and Akt phosphorylation in human glioma cell lines. Oncogene. 2009; 28: 3121-3131.

[9] Fallahian F, Karami-Tehrani F, Salami S, Aghaei M. Cyclic GMP induced apoptosis via protein kinase $\mathrm{G}$ in oestrogen receptor-positive and -negative breast cancer cell lines. The FEBS Journal. 2011; 278: 3360-3369.

[10] Wu Y, Chen Y, Qu R, Lan T, Sang J. Type II cGMP-dependent protein kinase inhibits EGF-triggered signal transduction of the MAPK/ERK-mediated pathway in gastric cancer cells. Oncology Reports. 2012; 27: 553-558.

[11] Jiang L, Lan T, Chen Y, Sang J, Li Y, Wu M, et al. PKG II inhibits EGF/EGFR-induced migration of gastric cancer cells. PLoS ONE. 2013; 8: e61674.

[12] Thomas MK, Francis SH, Corbin JD. Substrate- and kinasedirected regulation of phosphorylation of a cGMP-binding phosphodiesterase by cGMP. The Journal of Biological Chemistry. 1990; 265: 14971-14978.

[13] Breuza L, Halbeisen R, Jenö P, Otte S, Barlowe C, Hong W, et al. Proteomics of endoplasmic reticulum-Golgi intermediate compartment (ERGIC) membranes from brefeldin A-treated HepG2 cells identifies ERGIC-32, a new cycling protein that interacts with human Erv46. The Journal of Biological Chemistry. 2004; 279: 47242-47253.

[14] Garrett TPJ, McKern NM, Lou M, Elleman TC, Adams TE, Lovrecz GO, et al. Crystal structure of a truncated epidermal growth factor receptor extracellular domain bound to transforming growth factor alpha. Cell. 2002; 110: 763-773.

[15] Massironi S, Zilli A, Cavalcoli F, Conte D, Peracchi M. Chromogranin a and other enteroendocrine markers in inflammatory bowel disease. Neuropeptides. 2016; 58: 127-134.

[16] van Schaftingen E, Gerin I. The glucose-6-phosphatase system. The Biochemical Journal. 2002; 362: 513-532.

[17] Smirle J, Au CE, Jain M, Dejgaard K, Nilsson T, Bergeron J. Cell biology of the endoplasmic reticulum and the Golgi apparatus through proteomics. Cold Spring Harbor Perspectives in Biology. 2013; 5: a015073.

[18] Casas C. GRP78 at the Centre of the Stage in Cancer and Neuroprotection. Frontiers in Neuroscience. 2017; 11: 177.

[19] Kim YH, Kwak MS, Park JB, Lee SA, Choi JE, Cho HS, et al. N-linked glycosylation plays a crucial role in the secretion of HMGB1. Journal of Cell Science. 2016; 129: 29-38.

[20] Nebenführ A, Ritzenthaler C, Robinson DG. Brefeldin A: deciphering an enigmatic inhibitor of secretion. Plant Physiology. 2002; 130: 1102-1108.

[21] Viotti C. ER to Golgi-Dependent Protein Secretion: the Conventional Pathway. Methods in Molecular Biology. 2016; 1459: $3-29$.

[22] Wang X, Chung KP, Lin W, Jiang L. Protein secretion in plants: conventional and unconventional pathways and new techniques. Journal of Experimental Botany. 2017; 69: 21-37.

[23] Zhang YW, Rudnick G. Myristoylation of cGMP-dependent protein kinase dictates isoform specificity for serotonin transporter regulation. The Journal of Biological Chemistry. 2011; 286: 2461-2468.

[24] Thinon E, Serwa RA, Broncel M, Brannigan JA, Brassat U, Wright MH, et al. Global profiling of co- and post-translationally $\mathrm{N}$-myristoylated proteomes in human cells. Nature Communications. 2014; 5: 4919.

[25] Díaz B, Ostapoff KT, Toombs JE, Lo J, Bonner MY, Curatolo A, et al. Tris DBA palladium is highly effective against growth and metastasis of pancreatic cancer in an orthotopic model. Oncotarget. 2016; 7: 51569-51580.

[26] Gupta S, Roy M, Ghosh A. The Archaeal Signal Recognition Particle: Present Understanding and Future Perspective. Current Microbiology. 2017; 74: 284-297.

[27] Tardif S, Dubé C, Chevalier S, Bailey JL. Capacitation is associated with tyrosine phosphorylation and tyrosine kinase-like activity of pig sperm proteins. Biology of Reproduction. 2001; 65: 784-792.

[28] Nielsen H. Predicting Secretory Proteins with SignalP. Methods in Molecular Biology. 2017; 1611: 59-73.

[29] Tagliabracci VS, Engel JL, Wen J, Wiley SE, Worby CA, Kinch $\mathrm{LN}$, et al. Secreted kinase phosphorylates extracellular proteins that regulate biomineralization. Science. 2012; 336: 1150-1153.

[30] Tagliabracci VS, Pinna LA, Dixon JE. Secreted protein kinases. Trends in Biochemical Sciences. 2013; 38: 121-130.

[31] Bordoli MR, Yum J, Breitkopf SB, Thon JN, Italiano JE, Xiao $\mathrm{J}$, et al. A secreted tyrosine kinase acts in the extracellular environment. Cell. 2014; 158: 1033-1044.

[32] Sreelatha A, Kinch LN, Tagliabracci VS. The secretory pathway kinases. Biochimica Et Biophysica Acta - Proteins and Proteomics. 2015; 1854: 1687-1693.

[33] Klement E, Medzihradszky KF. Extracellular Protein Phosphorylation, the Neglected Side of the Modification. Molecular \& Cellular Proteomics. 2017; 16: 1-7.

[34] Worby CA, Mayfield JE, Pollak AJ, Dixon JE, Banerjee S. The $\mathrm{ABCs}$ of the atypical Fam20 secretory pathway kinases. The Journal of Biological Chemistry. 2021; 296: 100267.

[35] Gerlits O, Campbell JC, Blakeley MP, Kim C, Kovalevsky A. Neutron Crystallography Detects Differences in Protein Dynamics: Structure of the PKG II Cyclic Nucleotide Binding Domain in Complex with an Activator. Biochemistry. 2018; 57: 1833 1837.

[36] Rabouille C. Pathways of Unconventional Protein Secretion. Trends in Cell Biology. 2017; 27: 230-240.

[37] Stühler K, Schipper K, Poschmann G. Unconventional protein secretion: the hidden pathways. Biochimica Et Biophysica Acta - Proteins and Proteomics. 2019; 1867: 140272.

[38] Käll L, Krogh A, Sonnhammer ELL. A combined transmembrane topology and signal peptide prediction method. Journal of Molecular Biology. 2004; 338: 1027-1036.

[39] Wright MH, Paape D, Storck EM, Serwa RA, Smith DF, Tate EW. Global analysis of protein N-myristoylation and exploration of $\mathrm{N}$-myristoyltransferase as a drug target in the neglected human pathogen Leishmania donovani. Chemistry \& Biology. 2015; 22: 342-354.

[40] Cho YS, Park YG, Lee YN, Kim MK, Bates S, Tan L, et al. Extracellular protein kinase a as a cancer biomarker: its expression by tumor cells and reversal by a myristate-lacking Calpha and RIIbeta subunit overexpression. Proceedings of the National Academy of Sciences of the United States of America. 2000; 97: 835-840.

[41] Kang JH, Asai D, Toita R, Kitazaki H, Katayama Y. Plasma protein kinase $\mathrm{C}$ ( $\mathrm{PKC}$ )alpha as a biomarker for the diagnosis of 
cancers. Carcinogenesis. 2009; 30: 1927-1931.

[42] Harishchandran A, Nagaraj R. Interaction of a pseudosubstrate peptide of protein kinase $\mathrm{C}$ and its myristoylated form with lipid vesicles: only the myristoylated form translocates into the lipid bilayer. Biochimica Et Biophysica Acta - Proteins and Proteomics. 2005; 1713: 73-82.

[43] Maurer-Stroh S, Eisenhaber B, Eisenhaber F. N-terminal Nmyristoylation of proteins: prediction of substrate proteins from amino acid sequence. Journal of Molecular Biology. 2002; 317: 541-557.

[44] Wright MH, Heal WP, Mann DJ, Tate EW. Protein myristoylation in health and disease. Journal of Chemical Biology. 2010; 3: 19-35.

[45] Fothergill LJ, Furness JB. Diversity of enteroendocrine cells investigated at cellular and subcellular levels: the need for a new classification scheme. Histochemistry and Cell Biology. 2018;
150: $693-702$.

[46] Unsicker K, Huber K, Schütz G, Kalcheim C. The chromaffin cell and its development. Neurochemical Research. 2005; 30: 921-925.

[47] Tischler AS. Chromaffin cells as models of endocrine cells and neurons. Annals of the New York Academy of Sciences. 2002; 971: 366-370.

[48] Yang C, Gao J, Zhang J, Luo A. Enterochromaffin cells in the gut: a distant regulator of brain function? Gut. 2017; 67: $1557-$ 1558.

[49] Diwakarla S, Fothergill LJ, Fakhry J, Callaghan B, Furness JB. Heterogeneity of enterochromaffin cells within the gastrointestinal tract. Neurogastroenterology and Motility. 2017; 29: 10.1111/nmo.13101.

[50] Eiden LE, Jiang SZ. What's New in Endocrinology: The Chromaffin Cell. Frontiers in Endocrinology. 2018; 9: 711. 